Illinois State University

ISU ReD: Research and eData

Theses and Dissertations

8-25-2016

\title{
Understanding The Self-Efficacy Beliefs Of Preservice Learning And Behavioral Specialists During Their Practicum, Field-Based, And Student Teaching Semesters
}

\author{
Alice S. Cahill \\ Illinois State University, acahill1015@comcast.net
}

Follow this and additional works at: https://ir.library.illinoisstate.edu/etd

Part of the Special Education Administration Commons, Special Education and Teaching Commons, and the Teacher Education and Professional Development Commons

\section{Recommended Citation}

Cahill, Alice S., "Understanding The Self-Efficacy Beliefs Of Preservice Learning And Behavioral Specialists During Their Practicum, Field-Based, And Student Teaching Semesters" (2016). Theses and Dissertations. 608.

https://ir.library.illinoisstate.edu/etd/608

This Dissertation is brought to you for free and open access by ISU ReD: Research and eData. It has been accepted for inclusion in Theses and Dissertations by an authorized administrator of ISU ReD: Research and eData. For more information, please contact ISUReD@ilstu.edu. 


\title{
UNDERSTANDING THE SELF-EFFICACY BELIEFS OF PRESERVICE LEARNING AND BEHAVIORAL SPECIALISTS DURING THEIR PRACTICUM, FIELD-BASED, AND STUDENT TEACHING SEMESTERS
}

\begin{abstract}
Alice S. Cahill
100 Pages

The study of self-efficacy has become a dominant topic in psychological and educational research over the last 50 years. However, little information is known about preservice teachers' self-efficacy beliefs and even less about preservice special education teachers' self-efficacy beliefs. This study was designed to survey the self-efficacy beliefs of preservice special educators who are working in schools as part of their preservice college program.
\end{abstract}

The participants $(n=74)$ were special education preservice teachers in the Midwest in their practicum, field-based, or student teaching semesters. The participants completed a 24-question online survey on their self-efficacy beliefs. After completing a factor analysis of the survey, three factors emerged; Classroom Management, Instructional Strategies, and Student Engagement when working with children with special needs in either an academic or behavioral setting, and at various grade levels. Descriptive statistics, analysis of variance (ANOVA) tests, and post-hoc tests were used to determine how self-efficacy beliefs differed among preservice special education 
teachers. Classroom management was the only variable that was found to be significantly different between groups.

The results of this study showed that when comparing the three factors of Classroom Management, Instructional Strategies, and Student Engagement, preservice special education teachers in their student teaching placements reported higher selfefficacy in the area of Classroom Management than those in their field-based or practicum placements irrespective of type of program or grade level. Based on the study results, implications and recommendations for the field are provided.

KEYWORDS: Preservice Experiences, Preservice Special Education Teachers, SelfEfficacy Beliefs, Self-Perception 
UNDERSTANDING THE SELF-EFFICACY BELIEFS OF PRESERVICE LEARNING AND BEHAVIORAL SPECIALISTS DURING THEIR PRACTICUM, FIELD-BASED, AND STUDENT TEACHING SEMESTERS

ALICE S. CAHILL

A Dissertation Submitted in Partial Fulfillment of the Requirements for the Degree of DOCTOR OF EDUCATION

Department of Special Education

ILLINOIS STATE UNIVERSITY 
(C) 2016 Alice S. Cahill 
UNDERSTANDING THE SELF-EFFICACY BELIEFS OF PRESERVICE LEARNING AND BEHAVIORAL SPECIALISTS DURING THEIR PRACTICUM, FIELD-BASED, AND STUDENT TEACHING SEMESTERS

ALICE S. CAHILL

COMMITTEE MEMBERS:

Mark Zablocki, Chair

Stacey J. Bock

Christina Borders

John Rugutt 


\section{ACKNOWLEDGMENTS}

I would like to take this opportunity to thank the faculty at Illinois State University for their time, effort, and the education they provided so that I could successfully complete my doctoral degree in special education. First to my chairperson, Dr. Mark Zablocki, for his support and exceptional work ethic. Thank you for respecting me as a learner and helping me grow through this process. You have made me a better researcher, a better writer and, in turn, a better educator. To my committee members, Dr. Christy Borders who listens and communicates like no other, helping me know I can be successful; Dr. Stacey Bock, everyone's fearless leader, who offers amazing, sound advice while making you feel like you knew it already and she was just reminding you; and Dr. John Rugutt, a true expert in statistics (and patience) and whose mind fascinates me since it is so different than my own.

My parents always said I could be whatever kind of doctor I wanted to be when I grew up. I am pretty sure this isn't what they had in mind when they said that, but nothing makes me happier than working in education. Thanks Mom and Dad for planting that first seed.

To Barbara Luby, who encouraged me as a young teen to work with children with special needs. I'll always remember the day when I had my first ah-ha moment and I knew that this population was where my heart belonged. And to C. D., who, as a student in that classroom, showed me the way. 
To Dr. John McGraw, who sat with me on a June afternoon and changed the course of my life when he asked me what I wanted to be when I grew up (even though I was 35 years old). I'll never forget that talk and you can bet that I have shared your advice with other people!

To Drs. Bonnike, Jozwik, Moohr, and Zolkoski, who listened to me, proofread drafts, commiserated, and celebrated with me every step of your journeys and of mine. I love you four like no others, because you truly get this process and, in turn, truly get me.

To my babies, Sherman, Dixie, and Lucy, who sat, slept and played at my feet when I wrote, bugged me to get up so I wasn't sitting too long, and kept me from feeling lonely during this long process.

To my true love, my husband Kevin. Where do I begin? There are not enough words to describe how amazing you are and how much I love you. Education is not your field, yet you always listened to me when I was 'talking it out' (looking up words online when you didn't know what I was saying). You served as my cheerleader from day one, never faltering in your belief that I would be successful. You cooked, cleaned and took care of our loved ones so I could focus my energy where it needed to be each day. You held me when I cried, made sure I laughed often, and were my safe place to fall.

And finally, to God, through whom all things are possible. It took me a while to understand what (I think) you wanted me to do, and a bit longer to actually do it. Thanks for sharing your vision of 'the plan' with me once in a while. It really does help!

A. S. C. 


\section{CONTENTS}

Page

ACKNOWLEDGMENTS $\quad$ i

CONTENTS

TABLES Vi vi

CHAPTER

I. THE PROBLEM AND ITS BACKGROUND 1

Self-Efficacy 2

Bandura and Self-Efficacy 3

Measuring Self-Efficacy 5

Teacher Preparation and Self-Efficacy 6

Purpose of the Study $\quad 8$

$\begin{array}{lr}\text { Significance of the Study } & 9\end{array}$

$\begin{array}{ll}\text { Research Questions } & 10\end{array}$

Definition of Terms 10

$\begin{array}{ll}\text { Chapter Summary } & 12\end{array}$

II. REVIEW OF THE RELATED LITERATURE 13

$\begin{array}{ll}\text { Search Procedures } & 13\end{array}$

$\begin{array}{ll}\text { Psychometrics of Self-Efficacy } & 15\end{array}$

Rotter and the Rand Measure $\quad 15$

Gibson and Dembo's Teacher Efficacy Scale $\quad 16$

Tschannen-Moran and Hoy’s Teachers' Sense of Efficacy Scale 17

Testing the instrument 17

Testing the factor structure of the TSES 19

Use of the TSES to Measure Self-Efficacy 23

Self-Efficacy and Experiences in the Classroom 26

Impact of Preservice Teaching Experience on Self-Efficacy 28

Chapter Summary 
Research Design $\quad 35$

Instrumentation $\quad 36$

Demographics 36

Teachers' Sense of Efficacy Scale (TSES) 36

Reliability and Validity of the Instrument 37

$\begin{array}{ll}\text { Participants } & 38\end{array}$

$\begin{array}{ll}\text { Procedures } & 40\end{array}$

Collection of Data $\quad 41$

Select Survey 41

Selection and Cleaning of Data 42

Statistical Analysis $\quad 43$

Research Question 1

Factor Analysis $\quad 43$

Descriptive Statistics 45

Research Question 2

Research Question $3 \quad 46$

One-way Analysis of Variance $\quad 46$

Assumptions 46

$\begin{array}{ll}\text { Statistical Power and Effect Sizes } & 47\end{array}$

Chapter Summary $\quad 48$

IV. RESULTS 49

Chapter Overview $\quad 49$

$\begin{array}{lr}\text { Descriptive Statistics } & 50\end{array}$

Research Question 1

Factor Analysis $\quad 53$

Reliability $\quad 56$

Research Question 2

Research Question 3

$\begin{array}{ll}\text { Effect Size and Power } & 60\end{array}$

$\begin{array}{ll}\text { Chapter Summary } & 61\end{array}$ 
V. SUMMARY, CONCLUSIONS, AND RECOMMENDATIONS

Summary of the Research Problem, Methods, and Findings

Reliability of the TSES

Factor Analysis for Research Question $1 \quad 67$

Self-Efficacy of Preservice Teachers $\quad 69$

$\begin{array}{ll}\text { Implications } & 70\end{array}$

Limitations $\quad 71$

Recommendations for Future Research 73

$\begin{array}{ll}\text { Chapter Summary } & 77\end{array}$

$\begin{array}{ll}\text { REFERENCES } & 79\end{array}$

APPENDIX A: Email Request for Access to Class Lists 89

APPENDIX B: Recruitment Email 91

APPENDIX C: Consent Form 93

APPENDIX D: Survey Demographics 95

APPENDIX E: The Teachers' Sense of Efficacy Scale

(Tschannen-Moran \& Hoy, 2001) 


\section{TABLES}

$\begin{array}{lll}\text { Table Page } & \text { Pag }\end{array}$

1. Teachers' Sense of Efficacy Scale 44

2. Descriptive Statistics Using the Long Form of the TSES 52

3. Factor Loading for Factor Analysis with Varimax with Kaiser Normalization 54

4. Total Variance 56

5. Comparison of TSES Reliability Results 56

6. Differences in Factor Ratings by Clinical Placement 57

7. Classroom Management Tukey HSD 59

8. Differences in Factor Ratings by Classroom Type 60 


\section{CHAPTER I}

\section{THE PROBLEM AND ITS BACKGROUND}

Despite professional preparation, preservice teachers nationwide are not prepared to teach a diverse population of students, including those who exhibit academic or challenging behaviors (Leko, Brownell, Sindelar, \& Murphy, 2012; Pajares, 1992). This suggests that reading about students with challenges and actually providing an educational foundation for them in the classroom setting are very different things. Preservice teachers face experiences that test their skills, and typically have a set curriculum that they must get through each day, while still meeting the diverse learning and behavioral needs of their students. While using the strategies they learned and practiced in the safety of college coursework, they find they do not work like the textbook or their instructor told them they would work. Although preservice teachers initially are excited to teach all children, when faced with students with a variety of needs in their classrooms, they struggle with their inclusion (Avramidis, Bayliss, \& Burden, 2000). Through their experiences, preservice teachers' beliefs in their own competence, or their self-efficacy beliefs, begin to change (Pajares, 1992). While they once believed they could make a difference in all students' lives, their new experiences may force them to reassess their beliefs.

Self-efficacy is particularly important in the teaching profession. Education is the only field where students perceive themselves with expertise in their profession even before engaging in their professional preparation (Fajet, Bello, Leftwich, Mesler, \& 
Shaver, 2005). Preservice teachers enter teacher preparation programs with an abundance of prior knowledge about schools, classrooms, and instructional practices and therefore feel they have a firm working understanding of being a teacher due to their own experiences as students (Doolittle, Placek, \& Dodds, 1993; Stuart \& Thurlow, 2000). Preservice teachers choose their career paths based on their own experiences in the classroom and on their belief that they can make a difference in the lives of the children (Pajares, 1992). However, they fail to recognize that they now must learn how to teach students with educational abilities that are unlike their own.

This chapter will provide an overview and rationale of the study, define selfefficacy with explanations of the four main sources, the role of teacher education in higher education through national data and current knowledge of the factors contributing to self-efficacy, a review the purpose of the study, and the significance of this study to the field of special education.

\section{Self-Efficacy}

The study of self-efficacy has become a dominant topic in psychological research, and there have been numerous studies over the last four and a half decades on this matter (Chesnut \& Cullen, 2014; Dicke et al., 2014; Duffin, French, \& Patrick, 2012;

Pendergast, Garvis, \& Keogh, 2011). A generally agreed upon explanation of selfefficacy is that it refers to the perceived control over outcomes in a person's professional, social, and personal life. Self-efficacy is understood to influence feelings, thoughts, and behavior (Schunk \& Zimmerman, 2008). People who believe they can be successful will be and can lead more controlled and dynamic lives in the classroom and are then said to have high self-efficacy (Bandura, 1977, 1982, 1997; Gettinger, Stoiber, \& Koscik, 2008). 
People with a poor sense of self-efficacy may view their accomplishments in a more pessimistic way and feel they are not making the difference they hoped to in their classroom, hold little to no ownership over the obstacles in their lives, and are less likely to develop a commitment to their work. In contrast, people with a strong sense of selfefficacy may experience powerful thinking that provides them the confidence to follow their impulses, view challenging situations as learning experiences, and recover quicker from setbacks (Bandura, 1997). The development of self-efficacy is a continuous process and fluctuations can occur given new experiences in the classroom, verbal and non-verbal feedback from peers and people of influence, and a person's own state of mental being. Albert Bandura, who termed the psychological construct of self-efficacy, conducted some of the earliest research that formed the basis for the study of efficacy.

\section{Bandura and Self-Efficacy}

Albert Bandura devised the theoretical construct of self-efficacy looking through the lens of Social Cognitive Theory (Bandura, 1977). This theory posits that people learn by watching others and Bandura believed that outcomes are based more on what someone thinks they can do (versus what the outcomes show). In 1977, he published his seminal paper "Self-Efficacy: Toward a Unifying Theory of Behavioral Change." The subject of his paper has become one of the most studied topics in psychology and his work is considered the foundation from which other self-efficacy scales are built. Bandura (1986) explained that self-efficacy is influenced by mastery experience, verbal persuasion, vicarious experiences, and the physiological state. Mastery experience involves an individual's belief in his or her competency in doing a task. An individual measures the effects of what he or she did in a particular situation and makes judgments 
on it. Feeling he or she did a good job increases self-efficacy and, in contrast, the belief that he or she did not decreases self-efficacy (Bandura, 1997).

Self-efficacy is also influenced by verbal persuasion, which is represented in the feedback given on one's competency. Meaningful feedback can be provided by anyone an individual thinks has mastery knowledge on the subject, such as a cooperating teacher or professor. Verbal feedback can be positive, which can be reassuring and inspiring, or negative, which can lead to confusion and feelings of defeat (Bandura, 1986, 1997).

Vicarious experiences, a third source of efficacy, are experiences made by observation and modeling in a safe environment. Vicarious experiences can be particularly important for people who lack some of the self-confidence needed to maintain and increase their belief in their own self-efficacy. Additionally, peer modeling has a significant impact on the development of self-efficacy (Schunk, 1983; Schunk \& Zimmerman, 2007).

Finally, the physiological state, or physical and mental reactions like anxiety, stress, and fatigue that result from an experience, is critical in understanding self-efficacy beliefs. These reactions can shape self-efficacy and they are primarily from an internal locus of control (Bandura, 1997). Self-talk, or the voice in your mind that is both positive and negative, can and does influence the handling of situations both in and out of the classroom. It determines much of how you feel about who you are as a person. Understanding these physiological reactions determines how successful a person feels, and contours the effectiveness in the classroom (Pendergast et al., 2011).

Bandura (1997) explained that a person's sense of efficacy is fluid and that it is not necessarily the same given subject areas, tasks, or even groups of students. In an 
undated, unpublished instrument meant to begin to understand these differences without being too specific, Bandura created a 30-item survey with seven subscales: (a) efficacy to influence decision-making, (b) efficacy to influence school resources, (c) instructional efficacy, (d) disciplinary efficacy, (e) efficacy to enlist parental involvement, (f) efficacy to enlist community involvement, and (g) efficacy to create a positive school climate (Tschannen-Moran, Hoy, \& Hoy, 1998). However, the scale was not well received by people in the field of education, as they felt that this scale did not accurately measure what a teacher actually does in a classroom (Tschannen-Moran \& Hoy, 2001).

\section{Measuring Self-Efficacy}

Self-efficacy can be measured both quantitatively and qualitatively. Most studies over the last four and a half decades on self-efficacy have used online or face-to-face surveys. The results from these studies have been interpreted differently dependent on the researcher, study, measurement, and outcome (Tschannen-Moran \& Hoy, 2001; Tschannen-Moran et al., 1998), which has muddied the understanding of the concept. However, in the last decade, one self-efficacy scale has been used comprehensively, although not exclusively, throughout the world (Duffin et al., 2012). The Teacher's Sense of Efficacy Scale (TSES; Tschannen-Moran \& Hoy, 2001) measures self-efficacy through the lenses of Classroom Management, Instructional Strategies, and Student Engagement. These three areas are believed to encapsulate a teacher's responsibility in the classroom. However, there is a significant gap in the research related to preservice teachers (Caprano, Caprano, \& Helfeldt, 2010) and their self-efficacy beliefs. More information is needed to understand how these belief systems form (Moulding, Stewart, \& Dunmeyer, 2014) and what role they play in the classroom (Boe, Shin, \& Cook, 2007; 
Gettinger et al., 2008).

\section{Teacher Preparation and Self-Efficacy}

Nationwide, there is a huge difference in the amount of preparation, pedagogy, and field experience that preservice teachers receive across teacher education programs (Darling-Hammond, Chung, \& Frelow, 2002; Freeman, Simonsen, Briere, \& MacSugaGage, 2014). Preservice programs are shaped by the requirements of individual states with some general guidelines from the federal government (Freeman et al., 2014). Moulding et al. (2014) found that success alone in teacher preparation courses does not increase self-efficacy, which is why it is critical that preservice special education teachers have numerous experiences working in classroom environments. Preservice teachers who receive more hands-on training while in a university program have higher levels of self-efficacy in the classroom (Woodcock \& Reupert, 2013). While that self-efficacy level is high, as the preservice teachers know enough to be efficacious, they learn through experience that they do not have enough knowledge to stay efficacious (Dorel, Kearney, \& Garza, 2016).

Preservice teachers' attitudes (both positive and negative) toward student behavior and effective classroom management have their roots in self-efficacy. A preservice teacher's actions may demonstrate a poor sense of efficacy when they overly rely on consequences or have a negative attitude (Woolfolk, Rosoff, \& Hoy, 1990; Woolfson \& Brady, 2009) and, in turn, may see themselves as a less effective teacher. Classroom management skills are a critical part of being an effective teacher. However, upon a review of course syllabi, only $27 \%$ of the Institutes of Higher Education (IHE) offered an entire course on classroom management, while the remaining $73 \%$ embedded 
the topic into other courses (Oliver \& Reschly, 2010). Forty-nine states require instruction in classroom management for special education candidates, but that number drops to 45 for elementary teachers, 43 for secondary teachers and only 29 for alternative certification teachers (Freeman et al., 2014).

The lack of effective teacher preparation in classroom management has serious implications for the self-efficacy of preservice teachers. These include a perceived difficulty in working with students with challenging behaviors increasing the fear and anxiety of working with these students (D'Alonzo, Giordano, \& Vanleeuwen, 1997; Gable, Tonelson, Sheth, Wilson, \& Park, 2012). Inadequate preparation hinders the development of teachers' perceptions of their own abilities and those of their students. Preservice teachers who fail to develop a strong sense of efficacy then may fail to be an effective teacher. When they are unsure of how to use strategies to connect with their students both academically and behaviorally, they perceive that they are failing their students and themselves (Regan, 2009).

There are numerous studies on self-efficacy, but very few focus on preservice teachers, and only a handful include preservice special educators. When looking at efficacy, the largest amount of studies revolves around the student teaching experience. The results show that mastery experiences (through practicum and student teaching experiences) have the largest impact on the self-efficacy beliefs of preservice teachers (Brown, Lee, \& Collins, 2015; Tschannen-Moran \& Hoy, 2007).

A study was conducted in Israel researching if self-efficacy changed dependent on the participants' experiences working with students with academic and challenging behaviors and found that the years of preservice education had a positive correlation with 
self-efficacy (Leyser, Zeiger, \& Romi, 2011). This was especially true for preservice special education majors. Moulding et al. (2014) also found that, while in a practicum experience, preservice teachers felt more efficacious if they observed cooperating teachers who were successful in managing and engaging their students. Through those vicarious experiences, self-efficacy increased overall.

However, not all research has found an increase in self-efficacy after student teaching. Pendergast et al. (2011) discovered that when faced with the realities of an actual classroom, preservice teachers rated themselves poorly for self-efficacy beliefs. Pajares (1992) reiterated this in his review of research, when he found that preservice teachers' perceptions of teaching come from their own experiences as children. He maintains that the beliefs of what a teacher does in the classroom changes little even after coursework in higher education.

Little is known about the self-efficacy beliefs of only preservice special education teachers and how these change or develop over time. While some studies for this specific population looked at one factor or another (math or reading readiness), a study on the overarching beliefs of self-efficacy in the areas of classroom management, instructional strategies, and student engagement is missing. There has been no comparison between preservice special education teachers while in their different field experiences.

\section{Purpose of the Study}

Preservice special educators' perceptions of their self-efficacy are critical to their work as future educators (Pajares, 1992). The purpose of this research was to survey preservice special education teachers' perceptions of their efficacy while working in their practicum, field based, or student teaching experiences while enrolled at a large 
Midwestern university. Preservice special education teachers at this university are in the field during their junior-year practicum experience, which consists of at least 40 service hours, a senior year field based placement, and a senior year student teaching experience, which, together, culminate in over 1,000 hours of practical experience. I conducted a survey using the TSES to measure the Many factors are involved in preservice special education teacher programming, including the total number of clinical contact hours they have had, as well as types of students they have worked with (e.g., moderate to severe disabilities, high-incidence disabilities, low-incidence disabilities) during those mastery experiences. Because the population of preservice teachers where the study was conducted had the three semester-long experiences in an academic, behavioral, or life skills/adaptive setting, an analysis of the differences in those areas was also conducted.

\section{Significance of the Study}

The significance of this study may be seen in the contribution to the literature on self-efficacy and the use of the TSES with special education preservice teachers. Little to no research has been done on the self-efficacy beliefs throughout different practicum and field experiences for special education preservice teachers. Consequently, this study addressed a gap in the research. The main significance of this study may lie in the findings of the self-efficacy beliefs of preservice special education teachers. This study involved a specific population that is significant to institutions of higher education and teacher education programs, as well to preservice education researchers. 


\section{Research Questions}

The following research questions guided this study:

1. What factors emerge from an analysis of teachers' perceptions of self-efficacy using the TSES?

2. Is there a difference in the self-efficacy beliefs of preservice special education teachers in the factor areas of Classroom Management, Instructional Strategies, and Student Engagement across the levels of clinical placement?

3. Is there a difference in the self-efficacy of preservice special education teachers in the factor areas of Classroom Management, Instructional Strategies, and Student Engagement based on their classroom placement?

\section{Definition of Terms}

This study was designed to analyze preservice teachers' self-efficacy related to classroom management, student engagement, and instructional strategies. The conceptual definitions of the variables will be discussed in the following chapters.

Beginning teachers: A teacher in a public school who has been teaching less than a total of three complete school years.

Behavior management: Behavior management is the use of strategies and techniques to alter the actions of another person.

Challenging behavior: Challenging behaviors are identified as any behavior a preservice or practicing teacher finds to be difficult to manage. This can include any behavior that limits engagement in social interactions or learning.

Classroom management: Classroom management is often used as a synonym for behavior management. For the purposes of this study, it comprises three central 
components: time for instruction, instructional activities to get the most out of academic engagement and achievement, and proactive behavior management practices.

Disability: As defined by IDEA, the term "child with a disability" means a child with mental retardation, hearing impairments (including deafness), speech or language impairments, visual impairments (including blindness), serious emotional disturbance, orthopedic impairments, autism, traumatic brain injury, other health impairments, or specific learning disabilities; and who, by reason thereof, needs special education and related services.

Emotional disturbance: A condition exhibiting one or more of the following characteristics over a long period of time and to a marked degree that adversely affects a child's educational performance: (a) an inability to learn that cannot be explained by intellectual, sensory, or health factors; (b) an inability to build or maintain satisfactory interpersonal relationships with peers, and teachers; (c) inappropriate types of behavior or feelings under normal circumstances; (d) a general pervasive mood of unhappiness or depression; (e) a tendency to develop physical symptoms or fears associated with personal or school problems. Emotional disturbance also includes schizophrenia.

First-year teacher: A person in the first year of their teaching experience as a fully-qualified teacher.

Instructional strategies: Techniques teachers use to help students become independent learners.

Life skills/Adaptive: A placement setting focusing on transition training for adults with disabilities to live life as independently as possible. 
Preservice teacher: A person who is enrolled in a university or college-based education program.

Self-efficacy: A belief in one's owns ability, which refers to an individual's perception about his or her own capabilities to accomplish specific tasks. It can fluctuate over time based on the characteristics of given tasks. Bandura (1977) defined selfefficacy as "people's beliefs about their capability to exercise control over their own level of functioning and over events that affect their lives" (p. 257). In this study, self-efficacy beliefs were defined as a preservice teacher's belief in their own ability to work with students with academic or challenging behaviors.

SPSS: Statistical Package for the Social Sciences software.

Student engagement: The act of involving students in their own learning using motivational techniques to make progress in their educational goals.

Student teacher: A student who is practicing to be a teacher in a classroom fulltime under the observation of a fully certified teacher.

\section{Chapter Summary}

This chapter provided the theoretical background and the rationale for the study as well as introduced the topic of self-efficacy. It detailed the three research questions and provided the purpose and the significance of the study. While there a large amount of research on self-efficacy, there is a gap in the research on the self-efficacy beliefs of preservice teachers and a critical need for more research on self-efficacy of special education preservice educators working with students with academic or behavioral challenges. 


\section{CHAPTER II}

\section{REVIEW OF THE RELATED LITERATURE}

The purpose of this literature review was to examine the existing research on selfefficacy. This review focused on the (a) search procedures, (b) psychometrics of selfefficacy, (c) use of TSES to measure self-efficacy, (d) self-efficacy and experiences in the classroom, and (e) impact of preservice teaching experience on self-efficacy. This review demonstrated a gap in the literature regarding the study of self-efficacy among preservice teachers, especially those studying special education.

\section{Search Procedures}

I conducted a comprehensive computer search of the following online databases using a three-step procedure. In the first step, using Academic Search Complete, Education Full Text, Educational Resources Information Center (ERIC), ProQuest (dissertation databases), Psyc Info, and SAGE Journals, I searched the term teacher selfefficacy and it resulted in just over 129,200 sources. I limited the search to the years 1965 through 2015, based on the RAND Study that first introduced the concept of teacher efficacy. The number was cut to 125,990 . I continued the search adding the key term challenging behaviors, and it resulted in 44,900 sources. Adding another limiting term teachers' sense of efficacy scale dropped the total to 26,600. Adding the limiting terms preservice teacher preparation and special education preservice teachers resulted in 4,100 items. This number is deceivingly high as not all items truly covered the topic. Finally, the word inclusion was added as a limiting search term because that term 
narrowed preservice teacher beliefs to one aspect of their training. The result total dropped to 666 items. After a review of titles and abstracts, just over 440 items were pulled for review, excluding articles for various reasons including not being written in English, the focus not being on self-efficacy or preservice teachers, and articles that were not empirical.

A second step involved an archival hand search of the reference lists and footnotes from relevant self-efficacy studies, dissertations, and studies on preservice teacher education to locate additional articles that did not emerge from the online method of searching. In total, 172 articles, books, and other documents were determined to be of importance due to their role in the research of preservice education, self-efficacy, or special education self-efficacy, or their importance to other studies.

To determine which articles to include in the review, for step three I established three criteria. I opted to include only materials that: (a) concentrated on preservice teachers both nationally and internationally, (b) utilized the Teachers Sense of Efficacy Scale (TSES) in their study or a similar efficacy scale that was historically important to the study of efficacy, and (c) noted when special education preservice teachers were included in the study population. Based on these three criteria, this literature review contained 17 articles.

I will describe the literature on the psychometrics of self-efficacy, as this helps with the interpretation of quantitative psychological measurement tests. Next, I will review the literature on self-efficacy and the constructs of the TSES and for academic and behavioral challenges. Finally, I will describe the literature on self-efficacy and the preservice teacher. This review will demonstrate a gap in the literature regarding the 
study of self-efficacy among preservice teachers especially those preparing to be special educators.

\section{Psychometrics of Self-Efficacy}

Psychometrics is a field of study concerned with the theory and procedures of psychological measurement that includes information as well as personality traits, abilities, and attitudes (Maurer \& Pierce, 1998). Its primary focus is the study of differences between individuals. Psychometrics involves two major research responsibilities: (a) the construction of instruments and procedures for measurement and, (b) the development and refinement of theoretical approaches to measurement. To date, several self-efficacy and teacher efficacy surveys have been published, but three have had the most impact in the field.

\section{Rotter and the Rand Measure}

The Rand Corporation conducted the first psychology-based studies on teacher efficacy, funded by the United States government. The studies were grounded in J. B. Rotter's social learning theory. Rand's study of teacher efficacy resulted from data-based observations which showed that a person who viewed something as a reward because of something he or she specifically did was different from a reward given to that person for something over which he or she had no control (Rotter, 1966). Efficacy was built on the concept of locus of control. Rand's study led to a two-statement questionnaire that first introduced the term teacher efficacy. Using the Rand measure, and based on the achievements of reading programs and interventions, teachers were asked whether they believed that the reason for a student's success came from outside the school environment (external locus of control) or whether a teacher can teach to any child, 
regardless of student motivation (internal locus of control) (Armor et al., 1976). This measure focused on the idea of environmental factors influencing student learning with teachers feeling that features outside of their classrooms (e.g., home life, the community, or socioeconomics) controlled students' success in their classrooms. However, if a teacher could overcome those difficulties, he or she was labeled as having a high personal teaching efficacy (or the belief that the teacher could make a difference in the learning of a child). The Rand study was the basis for the development of many other instruments, also designed to measure self-efficacy (Tschannen-Moran \& Hoy, 2001).

\section{Gibson and Dembo's Teacher Efficacy Scale}

The Teacher Efficacy Scale (Gibson \& Dembo, 1984) was one of the first attempts to merge the Rand measure and Bandura's conceptualizations of efficacy as a personal measurement of success in teaching (Duffin et al., 2012). Using observations when providing feedback, Gibson and Dembo determined that teacher efficacy is “...multidimensional..." and "...may influence certain patterns of behavior known to yield achievement gains" (p. 579). Their belief was that a teacher's sense of efficacy is in direct correlation with his/her effectiveness. Gibson and Dembo admitted that further investigation was needed. Some of their interpretations were also questioned by researchers in the field (Woolfolk et al., 1990). Despite this skepticism, almost half of the studies on efficacy until 1998 were conducted using this tool to determine the selfefficacy beliefs of both in-service and preservice teachers (Tschannen-Moran et al., 1998). 


\section{Tschannen-Moran and Hoy's Teachers' Sense of Efficacy Scale}

In response to the many unresolved issues with the multitude of teacher selfefficacy scales that were developed in the 1980s and 1990s, Tschannen-Moran and Hoy (2001) developed the Ohio State Teacher Efficacy Scale (OSTES), now called the Teachers Sense of Efficacy Scale, as the developers preferred that name. They were concerned about the continued confusion regarding the framework of teacher efficacy (Tschannen-Moran \& Hoy, 2001; Tschannen-Moran et al., 1998). The scale was first developed during a seminar on self-efficacy at The Ohio State University. Two researchers, two educators, two full-time doctoral students, and four in-service teachers each created a list of what they thought were the foundations of teaching. Each member reviewed an undated 30-item teacher self-efficacy scale developed by Bandura, selected items that were important to teaching, and identified 8-10 new items they felt were not addressed in the scale. When all ideas were combined, the list was over 100 items long. After discussing the items, and utilizing 23 items from Bandura's 30-item scale, 52 items were written for testing.

Testing the instrument. In the first study, 146 preservice and 78 in-service teachers were surveyed at The Ohio State University using a 9-point scale, where teacher's perception of their influence to impact change was rated from 9, "a great deal", to 1 "nothing" (Tschannen-Moran \& Hoy, 2001). There were also scale anchors at 3 (very little), 5 (some influence), and 7 (quite a bit). In this study, in addition to completing the survey using the scale above, the participants rated the importance of all 52 items on a 4-point scale from "critical" to "not at all." The researchers conducted a factor analysis using varimax rotation with the 52 questions. Ten significant factors 
emerged with eigenvalues greater than one that explained $57.2 \%$ of the variance.

Questions with the highest validity were identified, reducing the total number of items to 32.

A second study by the same researchers completed at three universities (Ohio State, William and Mary, and Southern Mississippi) included 217 participants using the 32 items identified after the last study. Seventy preservice and 147 in-service teachers completed the instrument. Using the same factor analysis, the authors identified three main factors: efficacy for Classroom Management, efficacy for Student Engagement, and efficacy for Instructional Strategies. Eight significant factors emerged with eigenvalues greater than one that explained $63 \%$ of the variance. This minimized the total to 18 questions with the highest validity. Because the researchers felt that the questions for management needed the support of more questions, a third study was proposed with 36 items.

The three same universities involved in the second study, as well as teachers from two elementary schools, one middle school, and one high school, participated in the third study. The participants included 103 preservice teachers and 255 in-service teachers. The results of the study confirmed that the three factors from Study Two (efficacy for Classroom Management, efficacy for Student Engagement, and efficacy for Instructional Strategies) were able to be isolated and led to a total of 24 questions based on selecting the highest reliabilities determined by analyzing the means and eigenvalues greater than one. The researchers wanted to know if the items on the 24-question scale (long form) could be pared down to a viable shorter scale. The top four questions with the highest reliabilities for each of the factors created a 12-question scale (short form). The TSES is 
considered a reliable and valid instrument, ranking from moderately to highly reliable for both the short and long form of the TSES.

Using 111 preservice and 255 in-service teacher responses, the scales were "subjected to two separate factor analyses [and it] appeared that the best solution for preservice teachers was a single factor" (Tschannen-Moran \& Hoy, 2001, p. 799). The authors argued that since preservice teachers have little to no experience, the subscale scores may mean less to them and the full scale or long form (24 items) is the best measure of their self-efficacy. They also contended that their tool

...is superior to previous measures of teacher efficacy in that it has a unified and stable factor structure and assessed a broad range of capabilities that teachers consider important to good teaching, without being so specific as to render it useless for comparisons of teachers across contexts, levels and subjects. (pp. 801802)

The TSES is one of the most used efficacy scales both nationally and internationally (Duffin et al., 2012). However, since the original study, controversy surrounding the factor structure (3-factor or 1-factor) remains (Duffin et al., 2012; Fives \& Buehl, 2009; Poulou, 2007). The debate surrounds the judgment of whether preservice teachers can differentiate between and influence the three factors being measured. To date, three studies have focused on preservice teachers and the factor structure of the TSES.

Testing the factor structure of the TSES. One of the first studies to determine if preservice teachers can differentiate between the three factors being studied in the TSES was a 2007 study by Maria Poulou. A total of 198 fourth-year students from two universities in Greece, who had completed their student teaching, were given a translated TSES survey to determine if their beliefs about classroom management and student 
engagement were already forming and how those beliefs affected the instructional strategies being used (Poulou, 2007). Specifically, the researchers were looking for the preservice teachers' perceptions of the sources of efficacy, what their perceived levels of efficacy were for Classroom Management, Instructional Strategies, and Student Engagement, and if there was a relationship between those sources and the perceived levels of efficacy. The 3 -factor solution was examined by conducting a chi-square analysis, comparing it with a single-factor model of general teacher efficacy. The results showed "that the 3-factor solution was a significantly better fit than the single-factor model" and that for "the 3-factor model, all standardized path coefficients were found to be statistically significant" (Poulou, 2007, p. 207). The preservice teachers were able to differentiate between the three factors being studied, but also they were able to identify the one in which they felt the strongest.

Fives and Buehl (2009) examined the factor structure of the short and long forms of the TSES. They surveyed 102 in-service and 270 preservice American teachers using the long form (24 questions). The current years of schooling and previous experience for the preservice teachers were not identified. Their research questions were based on: (a) the understanding if the factor structure was different for practicing and preservice teachers, (b) how comparable the practicing and preservice teachers' responses were utilizing each form, and (c) if previous findings in the literature could be replicated. To address their research questions, an analysis of both the long and short forms (scores were taken from the completed long form) was conducted using Horn's parallel analysis (to find eigenvalues), and a scree plot to report how many factors had eigenvalues greater than one. The researchers also determined reliability with Cronbach's alpha, and 
completed a one-way analysis of variance (ANOVA) for years of experience and teaching level. Fives and Buehl determined that the single-efficacy factor structure is appropriate for student teachers, the 3 -factor structure is appropriate for practicing teachers, and the responses of practicing and preservice teachers were comparable. With similar means and reliability, the long and short forms were appropriate for both groups, which is consonant with their findings in a previous study (Fives, Hamman, \& Olivarez, 2007), and with Tschannen-Moran and Hoy's (2001) study.

Duffin et al. (2012) also conducted a study looking at the factor structure of the TSES. Specifically, they wanted to know if the factor structure represented teacher efficacy as a unidimensional or a multidimensional latent construct because through their review of research, they found that there are disputes in the literature on which factor structure is best for preservice teachers. They sampled only preservice teachers who were educational majors but who fell across various disciplines. The first sample of 272 participants was invited to complete the long form survey using a paper questionnaire. This population was in the beginning course of their teacher education program. They were given written information on how to complete the questionnaires and how to return them. The second sample of 180 preservice teachers was also surveyed at the beginning of their academic program in the same course, but the survey was an expected activity in the course and was administered by a teaching assistant. Both surveys were given after the course had ended. Results were computed using a confirmatory factor analysis to test the two models (1-factor and 3-factor). The findings indicated that the 1-factor structure fit better for that specific population, as they viewed efficacy as a unidimensional construct. The authors contended that this was because preservice teachers cannot 
"differentiate between the various aspects of teaching captured by the TSES" (Duffin et al., 2012), as a result of the population being so new to the teacher education program. Results of the three studies of the factor structuring of the TSES were mixed. Poulou's 2007 findings contrasted with Fives and Beuhle's 2009 findings, and with Duffin et al. (2012). While all three studies used participants that were at the preservice level, they were at various points of their academic career. Poulou (2007) contended that the preservice teachers could tell the difference between the three factors, but her participants were at the end of their student teaching experience. Fives and Buehl (2009) and Duffin et al. (2012) stated that their participants could not, but included participants at the beginning and "in relevant courses" (Fives \& Buehl, 2009, p. 122). Although there is no definitive agreement in the research, the original authors of the study contend that for the preservice teacher population, the total score for the three sections is the most applicable for measuring self-efficacy as the "subscale scores have little meaning for prospective teachers who have yet to assume real teaching responsibilities" (TschannenMoran \& Hoy, 2001, p. 801).

The factor structure of the TSES is considered stable both in the long and short forms. The survey as a whole studies the level of control felt for the effective traits that are considered important to good teaching. These traits are first realized during teacher preparation programs, and can strengthen preservice teachers' beliefs in themselves, their knowledge of content, and their method and practice of teaching (Tschannen-Moran \& Hoy, 2001). Because efficacy beliefs are believed to be constant once they are set (Pajares, 1992; Woolfolk et al., 1990), it is critical that efficacy beliefs are formed and challenged during a preservice teacher's preparation for the classroom. 


\section{Use of the TSES to Measure Self-Efficacy}

Since the advent of research into teacher efficacy (Armor et al., 1976; Barfield \& Burlingame, 1974; Rotter, 1966), the belief construct of self-efficacy has consistently shown a close relation to effective teaching behaviors, specifically promoting positive classroom behavior and improving student academic achievement (Bandura, 1997;

Killoran, Woronko, \& Zaretsky, 2014; Pajares, 1992; Tschannen-Moran et al., 1998). In a 2012 review of research, Leko and colleagues showed that the pedagogical practices of traditional teacher education programs help increase self-efficacy. The researchers concluded through their literature review that an effective special education teacher is defined by:

(a) extended preparation in special education; (b) knowledge of teaching both elementary math and reading; (c) ability to apply knowledge to practice, though beginning special education teachers seem less able to apply their knowledge; (d) explicit, interactive instruction to promote student achievement; (e) high levels of student engagement during instruction; (f) effective classroom management; (g) a sense of responsibility for the learning of students with disabilities; (h) ability to consider the individual learning and behavioral needs of students with disabilities during instruction; and (i) a sense of teaching efficacy. (p. 2)

Preservice teachers need more opportunities for clinical experiences instructing and managing children. Those opportunities need to be in varied settings with increasing levels of complexity. Those mastery experiences will provide opportunities for specific feedback to help preservice teachers understand their own levels of efficacy. O'Neill and Stephenson (2012b) investigated the foundational understandings of 573 preservice teachers' self-efficacy in the area of classroom management through mastery experiences. The participants were in their last year of their program and completed the survey online. The goals of the study were to determine if mastery experiences in the 
clinical setting influenced overall efficacy, if the preservice teachers saw classroom management as a separate domain of teaching, and if other sources of information contributed to efficacy. They used the long form of the TSES, another efficacy inventory, and a follow-up survey with questions specific for the preservice population to create a new survey questionnaire they felt was the most appropriate for their participants. The results showed that the preservice teachers felt that outside experiences influence self-efficacy more than coursework. Moreover, while classroom management was a concern of the preservice teachers, they felt they could influence behavior in the classroom (O’Neill \& Stephenson, 2012a).

Looking at this idea that preservice teachers can influence behavior based on their own self-efficacy beliefs, Dicke et al. (2014) conducted a study to determine whether self-efficacy beliefs in the area of classroom management could predict burnout/emotional exhaustion. The researchers believed that teachers with a positive view of the management of a classroom were not as affected by exhaustion/burnout as preservice teachers with a negative view and thus influenced positive behavior in the classroom. They surveyed 1,227 German preservice teachers using an adapted German version of the TSES (long form) and the German version of the Maslach Burnout Inventory (short version). The preservice teachers were grouped into three categories, those working in a primary school placement, those working in a vocational high school program, and those working in a university high school program. The results implied that the researcher's hypothesis was correct for all three groups; higher self-efficacy in classroom management resulted in fewer disruptions and led to less feelings of burnout/exhaustion. 
A year later, with a random subsample from the first group of participants, they conducted a study to see if their hypothesis remained true and provided any further evidence. What they determined through both studies was that self-efficacy in the area of classroom management predicted exhaustion only when the efficacy beliefs were already low. Using the Mediation, Moderation, and Conditional Process Analysis, a RegressionBased Approach (MODMED), they also determined teachers with lower self-efficacy beliefs had more behavior problems in their classroom, which led to higher levels of emotional exhaustion. Their results indicated that if teacher education programs train for areas of stress, self-efficacy in classroom management increased, thus decreasing emotional exhaustion. Matching preservice teachers' needs and their specific program training produced student teachers with stronger self-efficacy. Preservice teachers with low self-efficacy who believe that they are unqualified to deal with specific challenging behaviors or other challenging situations that arise in the classroom are less likely to be successful educators because they have higher levels of burnout (Dicke et al., 2014).

Strong pedagogical preparation has positive effects on teacher performance and, ultimately, student achievement (Darling-Hammond, 2000, 2006; Shillingford \& Karlin, 2014). However, self-efficacy is often scored lowest in the area of instructional strategies among preservice teachers. Sisman (2014) used the long form and Turkish version of the TSES to survey preservice teachers about their self-efficacy beliefs. He also created a questionnaire to learn their opinions about the teaching program they just completed. Undergraduate students who just completed their formal programming were targeted and 153 teacher candidates participated. The data gathered through the TSES was analyzed through Statistical Package for Social Sciences (SPSS) software program (percentages, 
standard deviation and mean scores for each subscale). Results showed that, for this population, self-efficacy was low and, of the three areas studied by the TSES, the area of instructional strategies was scored the lowest. This may be because preservice teachers are given few opportunities to practice their skills in this area (Sisman, 2014), especially prior to student teaching.

\section{Self-Efficacy and Experiences in the Classroom}

Preservice teachers' beliefs about their own efficacy in performing the tasks that teaching requires are major contributing factors to almost all facets of effective teaching (Bandura, 1997; Ross, 1992; Tschannen-Moran et al., 1998). Beliefs are often set before a preservice teacher begins formal training (Doolittle et al., 1993; Pajares, 1992) and can be deeply engrained and almost impossible to change (Rokeach, 1968). However, as a preservice teachers complete their practicum and student teaching hours, their efficacy beliefs begin to change. Derosier and Soslau looked at this concept through interviewing three preservice teachers, two of whom were placed in a special education classroom. Their questions were focused on the relationship between teacher candidates' selfreported efficacy, concerns about their ability to manage behavior and their pupils' learning, and if their concerns changed before, during, and after the student teaching experience. Using a multiple case design and the constant comparative method (Merriam, 1998), and coding their results using a mix of a priori and open-coding procedures, they found that the longer the preservice teachers worked in the classroom, or the more clinical hours they completed, the more efficacious they felt. All three candidates listed classroom management as a concern each time they were interviewed. Post student teaching, balancing responsibilities was listed three times, also. 
Leyser et al. (2011) explored whether Israeli preservice teachers' efficacy (both general and special education) changed dependent on their experiences working with students with academic and challenging behaviors. The authors studied several components, including whether efficacy changed during preservice preparation. A modified Hebrew version of the TES (Gibson \& Dembo, 1984) was given as a face-toface survey to 992 preservice teachers. The results showed that the more years of study a preservice teacher has completed makes a difference in self-efficacy. In addition, all third- and fourth-year special education preservice teachers perceived themselves as more efficacious than their general education counterparts. That was especially apparent when the general education preservice teachers worked with a population of special education students. The more experience a student teacher had with students with special needs, the higher his or her overall self-efficacy. The study concluded that experiences working with children with disabilities heightened self-efficacy, and since special education preservice teachers spent more time with this population, their scores reflected higher levels of efficacy.

Shillingford and Karlin (2014) conducted a study with 230 undergraduate general and special education preservice teachers enrolled in a teacher education program. Specifically, they wanted to see if experiences (both personal and in the field), coursework, and knowledge of working with students with special needs affected efficacy. The researchers also wanted to know if there was a difference between the two preservice groups and if exposure while in a practicum experience to students identified with emotional or behavioral disorders (EBD) influenced efficacy in student engagement. Utilizing the long form of the TSES and a population-specific questionnaire, they found 
that self-efficacy was the lowest in the area of student engagement for both general education and special education preservice teachers, but that having a student identified as EBD in the classroom did not have an impact on self-efficacy. While the authors also reported low scores for the participants on knowledge of working with students identified as EBD, they felt this was due to lack of practicum experiences. Through the study, they determined that the engagement of students, especially with the use of evidence-based practices, helps increase overall self-efficacy as preservice teachers see student success leading to feelings of their own success.

\section{Impact of Preservice Teaching Experience on Self-Efficacy}

Pendergast and colleagues (2011) studied 76 graduate preservice teachers and questioned whether self-efficacy beliefs change between the beginning and end of formal programming. The researchers utilized the TSES once during the students' first semester and once during their last semester. The researchers found that the self-efficacy scores decreased in all three areas by the time the second survey was given, about 3 weeks into the second semester of a one-year program. They deduced that the decline was due to the reality of being in the classroom after practicum placements and that the participants typically overestimated their levels of efficacy during the first semester. Some of the misunderstanding lies in the fact that before preservice teachers participate in practical experiences, they think they know what a teacher does in the classroom due to their own experiences as children. Once in the experience, they learn that the reality they face in student teaching is often different from what they expected. Their findings were consistent with Bandura's 1977 report on the effects of the sources of efficacy (Pendergast et al., 2011). 
Brown et al. (2015) conducted a mixed-method research project studying the effects of student teaching on the self-efficacy beliefs of 66 preservice teachers during their final year of teacher preparation. Using the TSES (long form), they wanted to know to what extent student teaching impacted a sense of self efficacy, and which factors the student teachers perceived as the most valuable. They found that preservice teachers do benefit from the experience of student teaching and that, overall, they have a healthy sense of efficacy. The TSES results showed that preservice teachers in this study felt most efficacious in the area of Classroom Management and least efficacious in the area of Student Engagement, on both the pretests and posttests. The researchers were surprised by this conclusion, as this was not the area where the largest gain from pre to post student teaching occurred, which were Instructional Strategies. They had been expecting that, consistent with previous research, Classroom Management would be the area of greatest gain. For the qualitative portion of the study, the preservice teachers were asked which components of student teaching prepared them the most, and three components emerged: (a) hands-on teaching, (b) observations, and (c) relationships with cooperating teachers. The researchers concluded that the preservice teachers' benefitted from practical teaching programs and that, although their levels of efficacy were higher than the norm in the pre and posttests, a gain was still shown.

Brown et al. (2015) also examined the impact student teaching had on preservice teachers' perceptions of preparedness to teach. For this phase of the study, the researchers designed the Measuring Perceptions of Preservice Teachers' Preparedness multi-scale survey. The participants answered a 23-question survey, constructed utilizing the National Association for the Education of Young Children (NAEYC) standards for 
teacher preparation, and included one open-ended question looking for the element of the student teaching experience that was most valuable. An analysis was conducted similar to what had been done with the TSES, but looked at the subcategories described in the scale (pedagogical content knowledge, planning and preparation for instruction, classroom management, promoting family involvement, and professionalism). The student teachers responded that they felt prepared, but less so in the areas of family involvement and content knowledge. Overall, they thought that actual classroom experiences prepared them the most, through practicing in an actual classroom and their relationship with cooperating teacher.

The TSES has also been used in conjunction with other scales to examine the relationship between self-efficacy and relevant constructs. Chesnut and Cullen's (2014) study looked at the commitment levels of 209 preservice teachers through their selfidentified levels of efficacy to determine if there was a relationship between commitment to the field and self-efficacy. Using the short form of the TSES and the Vocational Exploration and Commitment Scale section of the Commitment to Career Choices Scale, the authors found a sound relationship between commitment and success in the participant's beliefs of self-efficacy. The researchers also found a sound relationship between self-efficacy and a commitment to entering the teaching profession. As their perceptions of self-efficacy increased, so did their satisfaction with teaching as a profession.

Lee et al. (2012) conducted a study with 130 preservice teachers examining feelings of preparedness upon completion of student teaching. Preservice teachers were surveyed using a researcher-designed survey instrument, which included historical (i.e., 
how they felt at the beginning of student teaching) and current (i.e., how they felt now) questions. The researchers found that the mean differences of all items showed significant differences in the areas of pedagogical content knowledge, planning, and preparation for instruction, classroom management, working with families, and professionalism. The largest mean difference was an increase in Classroom Management and use of Instructional Strategies. In addition, preservice teachers felt that placement in an urban setting prepared them better to meet the needs of students with diverse educational backgrounds (Lee et al., 2012).

Preservice teachers reported that field experiences (mastery experiences) were the most influential part of their training, which is consistent with Bandura's $(1977,1997)$ social cognitive theory. Moulding, et al. (2014) researched the relationship between the self-efficacy levels of student teachers and their perceptions of encouragement from cooperating teachers and university supervisors during their mastery experience. The study used two different tools, the TSES (short form) and part C of their state preservice teacher survey (Part C, perceptions of student teaching experiences). Seventy-six elementary preservice teachers were surveyed once they completed their student teaching assignments. Preservice teachers' perceptions of how much support they were receiving did correlate with higher TSES scores. The researchers found that the quality of the placement (i.e., successfulness of the cooperating teacher) was also a factor in the selfefficacy beliefs of the preservice teachers. When preservice teachers see their cooperating teachers help their students be successful they feel more successful themselves. Those vicarious experiences produce feelings of increased self-efficacy (Moulding et al., 2014). 


\section{Chapter Summary}

The self-efficacy beliefs of practicing teachers are a well-studied topic for good reason. From the beginning, the self-efficacy construct has consistently shown a close relation with the teaching behaviors identified with promoting positive classroom behavior and advanced student achievement (Lancaster \& Alan, 2007; Pajares, 1992; Tschannen-Moran \& Hoy, 2007). It has also been shown that people tend to engage in actions and conditions in which they feel trained and skilled (positive self-efficacy), and avoid those where they doubt their potential to be successful (Bandura, 1977, 1986, 1997). Self-efficacy has been shown to be related to the types of teaching methods employed (i.e., instructional strategies), the amount of preparation in which the teacher engages prior to the lesson (i.e., management of the classroom), and the overall engagement of teachers with their students (i.e., student engagement) (Tschannen-Moran $\&$ Hoy, 2007). These are critical areas for preservice teacher development, too. Researching preservice teachers' beliefs is especially important, as they may not feel comfortable working with students with academic or behavioral needs due to a lack of specific training or experience in these areas. Student teaching is a critical piece of a

preservice education for increasing self-efficacy (Brown et al., 2015; Leyser et al., 2011; Moulding et al., 2014). Preservice experiences in the classroom lead to an overall understanding of what it takes to be an effective teacher, especially if the preservice teacher has observed a successful in-service teacher.

This chapter has examined the factor structure and validity of the TSES, which has become one of the most used self-efficacy scales for teachers (Duffin et al., 2012). It has also focused on the critical role self-efficacy plays in teacher preparation programing 
and effective teaching. Preservice teachers come into teacher education programs thinking they know what it takes to be effective, successful teachers (Pendergast et al., 2011). They have had years in the classroom as students, and believe they know why the teachers who made the largest impact on them did so. However, they may lack the knowledge of what truly makes a good teacher. Efficacy among preservice teachers tends to be high in the beginning of teacher education programs but decreases or changes as the realities of what it is like to actually manage a classroom, use instructional strategies, and engage students in meaningful ways becomes evident during student teaching experiences.

Research on efficacy has been conducted for over 50 years, and several researchers have developed quality surveys for understanding the role it plays in education. However, there remain gaps in the research regarding the self-efficacy beliefs of special education preservice teachers and several other variables, such as the amount of clinical contact hours with students in the classroom setting, and the population of special education students they are working with at the time of the studies. These are important variables to research as teacher education programs strive to meet the reality of changing populations in the school systems, including at the college level. In addition, a gap can be found in the research studying preservice special education teachers exclusively in critical areas such as overall efficacy and efficacy of Classroom Management, Instructional Strategies, and Student Engagement. Working with students in academic and behavioral settings requires parallel skill sets, but they are challenged by the different needs of individuals. These skills, while taught in the college classroom, are honed through vicarious and mastery experiences. Perceptions of this training can 
influence the self-efficacy beliefs of preservice teachers.

Given the aforementioned gaps in the literature, this study investigated undergraduate preservice special education teachers' self-efficacy, while working with students placed in one of three special education settings, academic, behavioral or life skills/adaptive. It also examined whether or not the number of clinical hours the preservice special educators had in the classroom changed their belief in their own selfefficacy. Research has shown that once self-efficacy beliefs are set, they are nearly impossible to change (Pajares, 1992; Woolfolk et al., 1990) and that the most important factor in determining teachers' sense of efficacy are their experiences (Bandura, 1977, 1997). Understanding how and why preservice special education teachers form the selfefficacy beliefs they do affects other facets of education. Efficacy is connected to educational outcomes such as instruction, eagerness and perseverance, as well as loyalty to the field of education. 


\section{CHAPTER III}

\section{METHODOLOGY}

This chapter provides a description of the research focus and methodology that guided this study. Included in this chapter are descriptions of (a) research design, (b) instrumentation, (c) participants, (d) procedures, and (e) statistical analysis.

This study was designed to investigate undergraduate preservice special education teachers' self-efficacy. The study examined if there was a difference in the self-efficacy of undergraduate preservice special education teachers in the areas of Classroom Management, Instructional Strategies, and Student Engagement as they worked with students with academic challenges, behavioral challenges, or in a life skills/adaptive classroom. Additionally, the impact of the number of clinical contact hours on selfefficacy was examined. Finally, any differences field placements made on self-efficacy were analyzed for both academic and behavioral placements.

\section{Research Design}

For this study, a cross-sectional survey design was utilized during the participants' practicum, field-based, and student teaching experiences. This type of design was chosen because it gathered data from one moment of time to assess the variables that the researcher was studying. Cross-sectional design studies do not provide causes of the characteristics looked at in the population because this design is predictive and correlational (Yakar, Can, \& Besler, 2013). 


\section{Instrumentation}

\section{Demographics}

The survey consisted of two parts. Part I (see Appendix D) was created to elicit specific information about the demographics of the groups. Those demographics included ones found in most surveys (gender, age, race), but also include some groupspecific questions. Participants were asked to identify their major (LBSI only or as a dual major which could include Deaf and Hard of Hearing or Low Vision and Blindness). Next, participants were asked which one of three types of settings they were currently in —academic, behavioral, or life-skills/adaptive — and in which one of three grade level placements: practicum, field based, or student teaching. Participants were also asked if their placement was in an elementary, middle school, or high school setting. If participants were in a practicum placement, the program sent them directly to the survey questions, as this was their first placement. If the participants were in a field-based placement, they were asked two additional questions (grade level and classroom type for their practicum placement) and if the participants were in their student teaching placement, they were asked four additional questions (grade level and classroom type for both practicum and field based placements).

\section{Teachers' Sense of Efficacy Scale (TSES)}

The TSES (Tschannen-Moran \& Hoy, 2001) was used as the second part of the survey for this study (see Appendix E). The researcher contacted the first author, Megan Tschannen-Moran, and the Copyright Clearance Center for permission to use the survey instrument via email. The scale, once known as the Ohio State Teacher Efficacy Scale (OSTES), was first developed during a seminar and measures both the teacher's 
assessment of personal teaching competence and an analysis of teaching tasks. The long form, which was chosen for this study, contains 24 questions that measure preservice educators' self-efficacy related to Classroom Management, Instructional Strategies, and Student Engagement, and was used for this study in an online format. Responses ranged on a modified Likert scale using a 9-point scale. Teacher's perceptions of their influence to impact change was rated from 9, "a great deal", to 1 "nothing". There were also response anchors at 3 (Very little), 5 (Some influence), and 7 (Quite a Bit).

The final instrument extracts teacher efficacy judgments in three factor domains: Instructional Strategies, Classroom Management, and Student Engagement (TschannenMoran \& Hoy, 2001). When the TSES study is given, subscale scores are not reviewed. Each time the survey is given different loadings can occur on the domains (Classroom Management, Instructional Strategies, and Student Engagement) based on a variety of factors such as population, age, experience, etc. Although some surveys can provide subscores, the TSES cannot based on inconsistent factor loadings. In order to establish subscores, the survey would have to go through rigorous test/retest reliability testing and consistently show the same factor loadings.

\section{Reliability and Validity of the Instrument}

The TSES (long and short versions) is considered a reliable and valid instrument. The TSES (long and short versions) is considered a reliable and valid instrument. Test reliability was established when Tschannen-Moran and Hoy (2001) used the instrument in multiple studies, in a test/retest method. Reliability for each of the factors in the original study by Tschannen-Moran and Hoy (2001) were: (a) Classroom Management $\alpha$ $=0.90$, (b) Instructional Strategies $\alpha=0.91$, (c) Student Engagement $\alpha=0.87$, and (d) 
total score $\alpha=0.94$. Several other studies (Duffin et al., 2012; Poulou, 2007) also replicated the data with similar results. Content validity was established while the instrument was being designed through a panel of researchers who compared the relevance of the test items to what was being measured (Tschannen-Moran \& Hoy, 2001).

There are three methods of assessing validity (Vogt, 2007). The first is content validity, or does the instrument measure what it is supposed to measure. It was assessed through expert opinion. Tschannen-Moran and Hoy (2001) assembled a panel of ten experts who reviewed the questions before testing. Criterion-related validity, a second method was done using concurrent validity where, during phase three of the development of this scale, the participants not only answered the 24 questions from the scale being designed, but also the questions from the Rand, and Gibson and Dembo scales. Positive correlations were found between the responses providing evidence of construct validity, which is the third method.

\section{Participants}

The participants in this study were selected from a convenience sample that included 74 undergraduate preservice teachers in the special education program of a large Midwestern university. Participants were majoring in a Learning and Behavioral Specialist I (LBSI) degree or a dual degree (LBSI and special education in the deaf and hard of hearing, or LBSI and special education in low vision and blindness). The study took place during their practicum experiences, their field based program, or their student teaching placement experience during the fall semester of 2015. At this large Midwestern university, special education majors have three semesters where they are out in the field. 
The junior-level class is the practicum experience during which participants spend approximately 40 hours in the field throughout the course of the semester. This is done while concurrently enrolled in other required courses. Two senior-level placements are also completed. The first-semester senior class is the field-based experience during which participants spend approximately 200 hours in the field throughout the course of the semester and is done while enrolled in three other required courses. The final course work in the field is student teaching and is a 16-week course. It is comprised of approximately 760 hours. In all placements, the preservice teacher's classroom responsibilities increase progressively and they are asked to provide evidence of their proficiency in classroom tasks such as planning, instruction, and assessment. All work done in the field is within programs for children with disabilities in schools, clinical facilities, community agencies, or residential institutions and is supervised.

For each placement, a classroom experience is provided focusing on students with academic needs, behavioral needs, or life skills/adaptive needs. In an academic needs setting, preservice teachers focus on students where the primary need is academic (i.e., students with learning disabilities). In a behavioral needs classroom, preservice teachers focus on students whose primary need is behavior (i.e., emotional disturbance). In a life skills/adaptive placement, preservice teachers focus on students who need life skill training to transition to living and working as independently as possible. Each special education preservice teacher has exposure to the three classroom types in either an elementary (K-5), middle (6-8), or high school (9-12) setting during their three-semester experience. 


\section{Procedures}

Permission to complete the study and to contact the teacher candidates through an emailed request was obtained and granted through the Institutional Review Board (See Appendix A). Participants received a recruitment letter via email informing them of the importance of the research study, and a brief explanation of what was needed from them (See Appendix B). The email was sent to the 223 preservice special education teachers identified through a list provided by the assistant chairperson in the special education department and the clinical and student teaching coordinator. Upon indication of the interest in participating in the study, they accessed the online survey via the link included in the email. Informed consent was indicated on the first page of the survey website (See Appendix C). Those who consented were redirected to the survey when they clicked "Agree" and asked the demographic questions once the survey was complete. The preservice teachers who clicked "I do not wish to participate" were taken to a screen that thanked them for their time and consideration. If a participant did not complete the survey in the first 15 days, a second request was made, and they were told that the survey would close in 15 days, giving participants a total of 30 days to complete the survey. Additionally, the survey was hosted on Select Survey, as the university involved in the study has an account with this company and they can provide technical support to researchers who use this software. Once the study began, participants were asked to complete a survey with 24 questions that used a 9-point Likert scale and close-ended questions. All participants were asked to complete $100 \%$ of the demographic and survey questions. This is what led them to be considered eligible for the study's results. Of the 223 participants, 90 began the survey. Sixteen stopped before completion of the entire 
survey. Complete and potential data came from $74(n=74)$ preservice teachers, which was $33.18 \%$ of all potential participants.

\section{Collection of Data}

The software to create and administer the demographic survey, the online survey, and the participant survey response data was done using Select Survey. All administered, deployed, and stored data was kept on a secured password access-only server at the university. The data was transferred in numeric form to an Excel file for analysis once the 30-day window had closed. The Excel file was uploaded into SPSS.

\section{Select Survey}

Select Survey is an online tool used to create and administer surveys. The Select Survey software is owned and licensed by the university where the study took place. Responses to the survey were saved in a database. They were accessible from any computer with an internet connection. The survey system used no public servers or commercially owned cloud servers. Two technical options available in the Select Survey were used to ensure anonymity of the participants. The first was "Forced Anonymous"; identifying information from the participants was removed, no matter how they took the survey. Using this technique, no information regarding the computer, network, IP address etc. was available. Another was "Single Response, Anonymous Access \& Allowed Updateable"; participants responded to the survey anonymously (without logging in) and were prevented from responding to the survey more than once. However, participants who returned to a completed survey were able edit their original responses. By using this option combined with "forced anonymous," respondents did not login, no identifying information was retained, and respondents only responded to the survey once. 
As a result, only the responses made to the questionnaire items were available to the researcher. The survey was available online for 30 days. The start date was the date that the email was sent to the participants.

\section{Selection and Cleaning of Data}

A total of 223 participants were sent the email to complete the study. No emails were returned undeliverable, so it was assumed that all emails were delivered. Participants received the email request for participation two times during the 30 days that the survey was open. The first time was on the day it opened (day 1). Sixty-five participants began the survey within 7 days; however, 14 of them did not complete the entire survey which eliminated them from the respondent group. The second time the survey was sent out was on day 15. Twenty-five participants began the survey, however 2 did not complete it, which eliminated them from the respondent group. This yielded a total of 90 participants who responded to the email by beginning the survey. Although 90 of the 223 potential participants began the survey, a total of 74 participants completed the survey. Select Survey does not provide information on where or when the participant stopped while filling out the survey, so that information remains unknown. After reviewing the data and excluding the eliminated participants, this survey yielded a $33.1 \%$ rate.

A full data set (completion of all questions) was chosen because the researcher wanted to understand the self-efficacy beliefs of the population being studied. Having complete data for all participants left no room for misinterpretation, or skewing of the mean and standard deviation (Vogt, 2007). This was important for interpretation of data because the study was done on a specific group of participants at one Midwestern 
university. During the process of performing statistical analysis using SPSS, pairwise deletion was chosen over listwise deletion due to the small sample size and to include as much data as possible.

\section{Statistical Analysis}

Quantitative methodology was used to analyze the data. For factor and comparative analysis, SPSS Statistical program software was used. The data input was checked by the researcher, twice, after it had been entered. Discussion of statistical analysis is arranged by research question.

\section{Research Question 1}

What factors emerge from an analysis of teachers' perceptions of self-efficacy using the TSES?

To answer research question 1, a factor analysis was conducted. This was compared to the factor analysis that was completed by Tschannen-Moran and Hoy (2001) for statistical differences. Eigenvalues, or the amount of variance in all the items explained by a factor, were also computed.

\section{Factor Analysis}

All survey data were transferred to Excel spreadsheets and then exported into the SPSS Statistical program. A factor analysis was conducted to determine if the survey data yielded the same three self-efficacy factors found in the original study (TschannenMoran \& Hoy, 2001). See Table 1 for the reported results. This step was taken as Tschannen-Moran \& Hoy (2007) encourage researchers to complete this step due to the variance in factors that have been found by other researchers. 
Table 1

Teachers' Sense of Efficacy Scale

\begin{tabular}{ll}
\hline Factors & Items \\
\hline Efficacy in Student Engagement & $1,2,4,6,9,12,14,22$ \\
Efficacy in Instructional Strategies & $7,10,11,17,18,20,23,24$ \\
Efficacy in Classroom Management & $3,5,8,13,15,16,19,21$ \\
\hline
\end{tabular}

Note. Reprinted from "Teacher efficacy: Capturing an elusive construct, by M.

Tschannen-Moran \& A. W. Hoy, 2001, Teaching and Teacher Education, 17, 783.

According to Tschannen-Moran and Hoy (2001), survey items for preservice teachers might only load on one factor, which would necessitate looking at a summed total efficacy score rather than in the three areas mentioned above. If the survey items had only fallen onto two factors for this survey, a $t$-test would have been needed to determine the difference in the means in the two factors.

Results from three other studies of the factor structuring of the TSES were mixed. Poulou's (2007) findings, whose participants were the most similar to the participants in this study, contend that preservice teachers can identify the differences between the factors. This was different than with Fives and Buehl (2009) and Duffin et al. (2012), whose participants were not as far in their education course work, who state that preservice teachers will load on one factor. The teacher's ratings of their self-efficacy were recorded on the long form using an online format. It contained 24 questions that measure preservice educators' self-efficacy related to the factors of Classroom Management, Student Engagement, and Instructional Strategies. Each participant's responses were rated on a 9-point scale, where teacher's perception of their influence to 
impact change was rated from 9, "a great deal", to 1 "nothing". The response anchors were also at 3 (Very little), 5 (Some influence), and 7 (Quite a Bit).

\section{Descriptive Statistics}

Descriptive statistics in the form of means and standard deviations were run for each question. According to Vogt (2007), in order to run a meaningful analysis of the data, the use of descriptive statistics as a tool is critical. They are used to tell who was chosen, why they were chosen, to describe the demographics of the sample, what methods were used to collect the data, and what was done with that data. This process is critical for replication of the study. There are four different types of descriptive statistics, two of which were computed for this study: (a) measures of central tendency, and (b) measures of dispersion. The measures of central tendency, specifically the mean, was calculated using the SPSS statistical package. The mean is critical to understanding the data because it gives an average of all scores, rather than looking at scores individually. The standard deviation (measure of dispersion) was also calculated.

\section{Research Question 2}

Is there a difference in the self-efficacy beliefs of preservice special education teachers in the factor areas of Classroom Management, Instructional Strategies or Student Engagement across the levels of clinical placement?

To answer research question 2, data was analyzed using an ANOVA. When a statistical difference was found in one of the factors, a Tukey HSD (honestly significant difference) post hoc test was completed. 


\section{Research Question 3}

Is there a difference in the self-efficacy of preservice special education teachers based on the population of students they teach whether in academic, behavioral or life skills/adaptive placements?

To answer research question number 3 , an ANOVA was completed to analyze the data.

\section{One-way Analysis of Variance}

Assumptions. There are three assumptions when looking at an ANOVA: (a) independence, (b) normal distribution, and (c) homogeneity of variance (Vogt, 2007). The independence assumption is the one that is most often neglected (Huck, 2004). The assumption of independence is measured by looking at the groups and seeing if they are influenced by each other. For this study, this assumption was met, as the groups were independent of each other. Another assumption is normal distribution. This distribution puts the majority of the scores in the middle (like a bell curve). It is "measured in standard deviation units or z-scores with a mean of zero and a standard deviation of 1 (Vogt, 2007, p25). The data were not normally distributed, so this assumption was violated. Had they been I would have run distribution, and a normal quantile plot looking for goodness of fit. The third assumption is homogeneity of variance. This was run to see if the scores on the dependent variables had constant variance. This is important because skewed results indicate that the scores are not normally distributed around the mean (Vogt, 2007). The variances were the same for all of the groups, so a scatter plot was done. The results indicated a moderate positive correlation. 
An ANOVA looks at the differences between the means of more than two groups (in this case, practicum, field based, and student teachers). The One-way ANOVA was used to analyze data of whether the means on a dependent variable between the groups is significantly different. The dependent variable in this study was self-efficacy in working with students with disabilities. The null hypothesis for this study was that there would be no difference in the mean scores of self-efficacy of preservice teachers in their first placement (practicum), their second placement (field based), and their final placement (student teaching) in all three factor sub scores of self-efficacy (Classroom Management, Instructional Strategies, and Student Engagement). When the null was determined not to be true, then a post-hoc test, using a Tukey adjustment, was conducted. A Tukey is a single-step multiple comparison technique. For this study, it was used in combination with an ANOVA between the three groups to find means with a statistically significant difference between different combinations of the groups (Green \& Salkind, 2014). The Tukey test was chosen to compare each mean to every other mean to see where the difference exists. The Tukey test corrects for family-wise error-rate (making one or more false discoveries). Graphical representation of participants' responses were represented in line graphs and tabular formats in Chapter IV. Using the appropriate scale, demographic variables were analyzed. For survey items with Likert-type scale responses, mean scores were calculated. In regards to the three research questions, factor analysis, and exploratory data analysis (ANOVA) were computed.

\section{Statistical Power and Effect Sizes}

Statistical power is "the probability of retaining (or not rejecting) a false null hypothesis" (Vogt, 2007, p. 142). As a researcher I wanted to make sure that my test 
statistic was large enough to accept the hypothesis if it was false. Researchers would like to obtain 0.80 statistical power (or a large difference) to decrease the chance of a Type II error (Huck, 2004). Typically, statistical power ranges from 0 to 1.0 , but it is possible to have higher than 1.0. In order to avoid making a Type I error, (rejecting a true null hypotheses) the level of statistical significance was set at $\alpha=0.05$. Once a null hypothesis is rejected, the chances of a Type II error (not rejecting the null hypothesis) become a concern. These differences are important as they set up the statistical power and effect size expectations.

The smaller the effect size number, the harder it is to meet the assumptions. In this study a statistical significance test, to see how big of a sample was needed, was not done prior to the data collection. However, a post-hoc estimate of power was done and reported with an effect size measure of practical significance (partial eta-squared).

\section{Chapter Summary}

Research for this study was conducted using a cross-sectional survey design. The instrument consisted of two parts, a demographic section and the TSES (TschannenMoran \& Hoy, 2001). Participants consisted of 74 undergraduate special education majors working towards an LBSI or a dual major of LBSI with low vision and blindness or deaf and hard of hearing. Select Survey was used as the collection device and transferred to an excel spreadsheet for further analysis. Factor analysis, means testing, and a one-way ANOVA was completed, with the addition of a post-hoc Tukey test, when necessary, using the IBM-SPSS statistical program. 


\section{CHAPTER IV}

\section{RESULTS}

This chapter presents the results of data analyses for the study on undergraduate preservice special education teachers' self-reported perceptions related to their self-efficacy in the areas of Student Engagement, Classroom Management, and Instructional Strategies. Results related to these analyses are presented in tables throughout the chapter. Descriptive statistics related to the sample and to items comprising the measures used within the study are presented. Result summaries related to the research questions framing the study and their analyses are concluded in the chapter. Presentation of these results is organized according to the three research questions. The results provided are as follows: (a) chapter overview, (b) descriptive statistics, (c) factor analysis of the instrument subscales), (d) a one-way Analysis of Variance (ANOVA), (e) a post-hoc analysis, and (f) chapter summary

\section{Chapter Overview}

Many factors are involved in preservice special education teacher programming, including the total number of clinical placement hours and type of classroom placement during those mastery experiences. Preservice educators' perceptions of their own selfefficacy are vital to their work as future educators (Brownell, Ross, Colon, \& McCallum, 2005; Hoy \& Spero, 2005; Pajares, 1992). It is not unreasonable to assume that there is a relationship between these placements and a preservice teacher's sense of self-efficacy. The goal of this study was to determine the self-efficacy beliefs in the areas of Classroom 
Management, Instructional Strategies and Student Engagement at a Midwestern university surveying preservice special education teachers who are in one of three clinical placements (practicum, field based, and student teaching) and in an academic, behavioral or life-skills/adaptive classroom placement. The null hypothesis is that there would be no difference in self-efficacy between preservice teachers in their first, second, and final placement in all three factor areas (Classroom Management, Instructional Strategies, and Student Engagement) in all three classroom placements.

\section{Descriptive Statistics}

First, I obtained a list of all eligible preservice special education teachers and their email addresses from the Assistant Chairperson in the Special Education department and the Clinical and Student Teaching Coordinator. Next, I sent the survey to 223 preservice LBSI special education candidates enrolled at a large Midwestern university in the fall semester of 2015. Complete and usable data came from 74 (33\%) preservice teachers. From this, $90.5 \%(n=67)$ identified as female and $8.1 \%(n=6)$ identified as male. One person chose the 'prefer not to answer' option. This was similar to demographic information given about the population of the program as a whole. Ages ranged from 21 $(\mathrm{n}=33,44.6 \%), 22(\mathrm{n}=26,35.1 \%), 23(\mathrm{n}=9,12.2 \%)$, and 24, 25 and 27 and above each holding the same number of participants $(n=2,2.7 \%)$. A high percentage of participants identified as White $(n=69,93.2 \%)$, Hispanic $(n=4,5.4 \%)$, and Black $(n=1,1.4)$ being the only other indicators. LBSI preservice teachers made up the majority of the participants $(n=70,94.6 \%)$, with some identifying as a dual major $(n=4,5.4 \%)$. Placement was separated into current and past placements (if appropriate). Practicum students $(n=13$, $17.6 \%)$, field-based students $(n=47,63.5 \%)$, and student teachers $(n=14,18.9 \%)$ 
identified their classroom placement (classroom type) as academic $(n=21,28.4 \%)$, behavioral $(\mathrm{n}=23,31.1 \%)$, and adaptive/life skills $(\mathrm{n}=30,40.5 \%)$ and their school level as elementary $(n=31,41.9 \%)$, middle school $(n=9,12.2 \%)$, and high school $(n=34,45.9 \%)$.

Participants were asked to choose a response using a 9-point scale, where teacher's perception of their influence to impact change was rated from 9, "a great deal", to 1 "nothing" (Tschannen-Moran \& Hoy, 2001). Scale anchors were also found at 3 (very little), 5 (some influence), and 7 (quite a bit). For scoring purposes and to understand the means and standard deviations of the answers from this population, I created titles identifying each even number's explanation. The odd numbered items remained the same as in the Tschannen-Moran and Hoy (2001) study and the even numbers were given similar titles for consistency. The titles then became: 1=Nothing, 2=Very, very little, 3=Very Little, 4=Little influence, 5=Some influence, $6=\mathrm{A}$ bit, 7=Quite a Bit, 8=A lot, and 9=A Great Deal.

The means and standard deviations were calculated for each question. The overall mean values for each question fell between 5.64 and 7.51, with question 22 (How much can you assist families in helping their children do well in school?) at the low end and question 17 (How much can you do to adjust your lessons to the proper level for individual students?) at the high end. Standard deviations fell between 1.09 and 2.07. Table 2 provides these descriptive statistics. 
Table 2

Descriptive Statistics Using the Long Form of the TSES

\begin{tabular}{|c|c|c|}
\hline & Mean & SD \\
\hline Q1. How much can you do to get through to the most difficult students? & 6.76 & 1.35 \\
\hline Q2: How much can you do to help your students think critically? & 6.61 & 1.33 \\
\hline Q3: How much can you do to control disruptive behavior in the classroom? & 6.41 & 1.40 \\
\hline $\begin{array}{l}\text { Q4: How much can you do to motivate students who show low interest in } \\
\text { school work? }\end{array}$ & 6.47 & 1.39 \\
\hline $\begin{array}{l}\text { Q5: To what extent can you make your expectations clear about student } \\
\text { behavior? }\end{array}$ & 7.42 & 1.25 \\
\hline $\begin{array}{l}\text { Q6: How much can you do to get students to believe they can do well in } \\
\text { school? }\end{array}$ & 7.34 & 1.19 \\
\hline Q7: How well can you respond to difficult questions from your students? & 6.68 & 1.33 \\
\hline Q8: How well can you establish routines to keep activities running smoothly? & 7.38 & 1.16 \\
\hline Q9: How much can you do to help your students value learning? & 6.78 & 1.24 \\
\hline $\begin{array}{l}\text { Q10: How much can you gauge student comprehension of what you have } \\
\text { taught? }\end{array}$ & 7.30 & 1.16 \\
\hline Q11: To what extent can you craft good questions for your students? & 7.04 & 1.24 \\
\hline Q12: How much can you do to foster student creativity? & 7.00 & 1.49 \\
\hline Q13: How much can you do to get the children to follow classroom rules? & 6.99 & 1.18 \\
\hline $\begin{array}{l}\text { Q14: How much can you do to improve understanding of a student who is } \\
\text { failing? }\end{array}$ & 6.49 & 1.46 \\
\hline Q15: How much can you do to calm a student who is disruptive or noisy? & 6.77 & 1.09 \\
\hline $\begin{array}{l}\text { Q16: How well can you establish a classroom management system with each } \\
\text { group of students? }\end{array}$ & 6.88 & 1.38 \\
\hline $\begin{array}{l}\text { Q17: How much can you do to adjust your lessons to the proper level for } \\
\text { individual students? }\end{array}$ & 7.51 & 1.21 \\
\hline Q18: How much can you use a variety of assessment strategies? & 6.85 & 1.66 \\
\hline $\begin{array}{l}\text { Q19: How well can you keep a few problem students from ruining an entire } \\
\text { lesson? }\end{array}$ & 6.78 & 1.25 \\
\hline $\begin{array}{l}\text { Q20: To what extent can you provide an alternative explanation or example } \\
\text { when students are confused? }\end{array}$ & 7.15 & 1.11 \\
\hline Q21: How well can you respond to defiant student? & 6.62 & 1.30 \\
\hline $\begin{array}{l}\text { Q22: How much can you assist families in helping their children do well in } \\
\text { school? }\end{array}$ & 5.64 & 2.07 \\
\hline Q23: How well can you implement alternative strategies in your classroom? & 6.74 & 1.64 \\
\hline $\begin{array}{l}\text { Q24: How well can you provide appropriate challenges for very capable } \\
\text { students? }\end{array}$ & 7.04 & 1.45 \\
\hline
\end{tabular}




\section{Research Question 1}

What factors emerge from an analysis of teachers' perceptions of self-efficacy using the TSES?

\section{Factor Analysis}

Confirmatory factor analysis, a technique to determine how well various items are related to one another and form clusters or factors, was conducted because the original TSES study and several subsequent studies found that certain items loaded differently on different factors depending on the types of participants. I wanted to determine if the current study's preservice special education teacher's responses loaded onto one or more factors, and if they were the same factors that had been identified by any of the researchers who had previously completed such analysis.

In the final version of the TSES instrument completed by Tschannen-Moran and Hoy (2001), three factors were identified. In my study, the factors originally defaulted to five. A confirmatory factor analysis was completed and data converged on the three factors leaving some questions not loading completely onto any factor. The principal component analysis was conducted using varimax rotation with Kaiser normalization (See Table 3). The rotation converged in seven iterations. Decision guidelines provided in Ellett et al., (1997) and Chemosit (2012), drove item loading decisions for this study: (a) the minimum value for retaining an item on a factor was 0.33 ; (b) an item was retained if it loaded primarily on one factor; (c) an item was retained on the factor on which its loading was greatest; and (d) if an item loaded on more than one factor, the item was retained if the difference of the squared loadings was 0.20 or greater. 
Table 3

Factor Loading for Factor Analysis with Varimax with Kaiser Normalization

\begin{tabular}{|c|c|c|c|c|}
\hline & Survey Item & 1 & 2 & 3 \\
\hline $\mathrm{Q} 1$ & $\begin{array}{l}\text { How much can you do to get through to the most difficult } \\
\text { students? }\end{array}$ & .69 & & \\
\hline Q2 & How much can you do to help your students think critically? & & & .59 \\
\hline Q3 & $\begin{array}{l}\text { How much can you do to control disruptive behavior in the } \\
\text { classroom? }\end{array}$ & .77 & & \\
\hline Q4 & $\begin{array}{l}\text { How much can you do to motivate students who show low } \\
\text { interest in school work? }\end{array}$ & & .51 & \\
\hline Q5 & $\begin{array}{l}\text { To what extent can you make your expectations clear about } \\
\text { student behavior? }\end{array}$ & & .50 & \\
\hline Q6 & $\begin{array}{l}\text { How much can you do to get students to believe they can do } \\
\text { well in schoolwork? }\end{array}$ & & 68 & \\
\hline Q7 & $\begin{array}{l}\text { How well can you respond to difficult questions from your } \\
\text { students? }\end{array}$ & & .56 & \\
\hline Q8 & $\begin{array}{l}\text { How well can you establish routines to keep activities running } \\
\text { smoothly? }\end{array}$ & & .58 & \\
\hline Q9 & How much can you do to help your students value learning? & & .49 & .43 \\
\hline Q10 & $\begin{array}{l}\text { How much can you gauge student comprehension of what you } \\
\text { have taught? }\end{array}$ & & .72 & \\
\hline Q11 & $\begin{array}{l}\text { To what extent can you craft good questions for your } \\
\text { students? }\end{array}$ & & .78 & \\
\hline Q12 & How much can you do to foster student creativity? & & 63 & \\
\hline Q13 & $\begin{array}{l}\text { How much can you do to get the children to follow classroom } \\
\text { rules? }\end{array}$ & .68 & & \\
\hline Q14 & $\begin{array}{l}\text { How much can you do to improve understanding of a student } \\
\text { who is failing? }\end{array}$ & & & .75 \\
\hline Q15 & $\begin{array}{l}\text { How much can you do to calm a student who is disruptive or } \\
\text { noisy? }\end{array}$ & .72 & & \\
\hline Q16 & $\begin{array}{l}\text { How well can you establish a classroom management system } \\
\text { with each group of students? }\end{array}$ & .75 & & \\
\hline Q17 & $\begin{array}{l}\text { How much can you do to adjust your lessons to the proper } \\
\text { level for individual students? }\end{array}$ & .34 & .42 & \\
\hline Q18 & How much can use a variety of assessment strategies & & & .62 \\
\hline Q19 & $\begin{array}{l}\text { How well can you keep a few problem students from ruining } \\
\text { an entire lesson? }\end{array}$ & .64 & & \\
\hline Q20 & $\begin{array}{l}\text { To what extent can you provide an alternative explanation or } \\
\text { example when students are confused? }\end{array}$ & .47 & .39 & .34 \\
\hline Q21 & How well can you respond to defiant student? & .57 & & \\
\hline Q22 & $\begin{array}{l}\text { How much can you assist families in helping their children do } \\
\text { well in school? }\end{array}$ & & & .75 \\
\hline Q23 & $\begin{array}{l}\text { How well can you implement alternative strategies in your } \\
\text { classroom? }\end{array}$ & & & .77 \\
\hline Q24 & $\begin{array}{l}\text { How well can you provide appropriate challenges for very } \\
\text { capable students? }\end{array}$ & & & .87 \\
\hline
\end{tabular}


Analysis of the 24-item survey for this population yielded a result of 12 items loading on one factor, 11 items loading on two factors and 1 item loading on all three factors. I labelled component one as Classroom Management because its questions related closest to the Classroom Management factor in the Tschannen-Moran and Hoy (2001) study. The same is true for component two, Instructional Strategies, and component three, Student Engagement.

These results were compared to the Tschannen-Moran and Hoy (2011) study results to see if the items loaded with the same factor consistently. In their study, all items loaded cleanly on to a factor after several trials. In this study, some items did not load cleanly onto any factors (the scores being less than the 0.33 ). This is consistent with previous studies by Duffin et al. (2012), Fives and Buehl (2009), and Poulou (2007), who found that each question did not always load the same as the original studies results.

Additional data determined through factor analysis are eigenvalues. Eigenvalues are a set of real numbers in a vector space related to a linear system of equations (Hoffman \& Kunze, 1971), that identify the total variance in participants responses explained by each factor. When looking at eigenvalues to determine how many factors are important, two things come into play: (a) factors with eigenvalues over 1.0 are the only ones used, and (b) a scree plot is run to determine where the factors even out to separate the factors that provide usable information (Vogt, 2007). For this study, at component six, the total eigenvalue dropped below one. A scree plot verified that factors 1-5 were showing the majority of variance. With this confirmation, components $1-5$ were determined to be the initial factor loading. I decided to use the first three factors to remain consistent with previous research and to be able to compare data with integrity. 
See Table 4 for the eigenvalues for each factor.

Table 4

Total Variance

\begin{tabular}{lrcc}
\hline & Eigenvalue & \% of Variance & Cumulative \% \\
\hline Classroom Management & 10.111 & 42.13 & 42.130 \\
Instructional Strategies & 1.987 & 8.28 & 50.408 \\
Student Engagement & 1.676 & 6.99 & 57.393 \\
\hline
\end{tabular}

\section{Reliability}

For each of the factors, a computation of Cronbach's alpha was conducted to check for the strength of the reliability of the factors, or the internal consistency of the scale. Reliabilities for each factor were $\alpha=0.87$ for Classroom Management, $\alpha=0.83$ for Instructional Strategies, and $\alpha=0.89$ for Student Engagement, and a combined total scale of $\alpha=0.92$. To be considered reliable, an alpha of 0.70 or higher is required (Vogt, 2007). Since this study used the same 24-question tool as Tschannen-Moran and Hoy (2001), I compared my reliability coefficients with their coefficients. The reliability coefficients in my study were comparable to the coefficients found in their study (see Table 5).

Table 5

Comparison of TSES Reliability Results

\begin{tabular}{ccccc}
\hline & $\begin{array}{c}\text { Classroom } \\
\text { Management }\end{array}$ & $\begin{array}{c}\text { Instructional } \\
\text { Strategies }\end{array}$ & $\begin{array}{c}\text { Student } \\
\text { Engagement }\end{array}$ & Total Scale \\
\hline $\begin{array}{c}\text { Tschannen-Moran \& } \\
\text { Hoy's 2001 TSES }\end{array}$ & 0.90 & 0.91 & 0.87 & 0.94 \\
\begin{tabular}{c} 
This study's TSES \\
\hline
\end{tabular}
\end{tabular}




\section{Research Question 2}

Is there a difference in the self-efficacy beliefs of preservice special education teachers in the factor areas of Classroom Management, Instructional Strategies, and Student Engagement across the levels of clinical placement?

To answer this question, I conducted an ANOVA to evaluate the relationship between the participants' clinical placement and the mean scores on the factors of Classroom Management, Instructional Strategies, and Student Engagement. I used an ANOVA because it is the best test to looks at the differences in the outcome variable means across the levels of the independent variable and determine whether the differences in means were significantly different (Handy, 2004). For clinical placement, three options existed: practicum (40 hours), field based (200 hours), and student teaching (760 hours). The factors across each clinical placement were compared. See Table 6 for differences between ratings on the three factors based on clinical placement.

Table 6

Differences in Factor Ratings by Clinical Placement

\begin{tabular}{llrccccc}
\hline Factor & Source & $d f$ & $F$ & $S S$ & $M S$ & $p$ & $\eta^{2}$ \\
\hline 1 & Corrected Model & 2 & 3.31 & 284.87 & 142.43 & 0.04 & 0.09 \\
& Error & 71 & & & & & \\
& Corrected Model & 2 & .66 & 41.61 & 20.80 & 0.05 & .018 \\
& Error & 71 & & & & & \\
& Corrected Model & 2 & 2.77 & 317.76 & 158.88 & 0.07 & 0.07 \\
& Error & 71 & & & & & \\
\hline
\end{tabular}

Note. $d f=$ degrees of freedom, $\mathrm{SS}=$ sums of squares, $\mathrm{MS}=$ mean squares, $F=\mathrm{F}$ distribution, $p=$ significance, $\eta^{2}=$ effect size, Factor $1=$ Classroom Management, Factor $2=$ Instructional Strategies, Factor 3=Student Engagement 
For the first dependent variable, the tests of between-subject's effects showed $F$ $(2,71)=3.31, p=0.04, \eta^{2}=0.09$, indicating significant differences across the levels of clinical placement variables. The $\eta^{2}$ of .09 indicates a moderate relationship between the Classroom Management factor and levels of clinical placement. For Instructional Strategies, the tests of between-subject's effects showed $F(2,71)=0.66, p=.05, \eta^{2}=$ 0.018 , indicating no significant difference in the levels of clinical placement. The $\eta^{2}$ of .018 indicates a small relationship between the Instructional Strategies factor and levels of clinical placement. For Student Engagement, the tests of between-subject's effects showed $F(2,71)=2.77, p=0.07, \eta^{2}=0.07$, indicating no significant differences across the three levels of clinical placement. The $\eta^{2}$ of .07 indicates a moderate relationship between the Student Engagement factor and levels of clinical placement.

Because the overall $F$ test was significant, I conducted a follow up Tukey HSD post-test to evaluate pairwise differences among the means. Since the assumption of homogeneity of variance was met, a Tukey HSD (honestly significant difference) test was completed for Classroom Management to determine where the significant difference between groups occurred. The results are displayed in Table 7 . The results of the Tukey test confirmed that there was a significant difference in means of perceptions of self efficacy for Classroom Management between the group in their practicum clinical placement and the group in their student teaching clinical placement. 
Table 7

Classroom Management Tukey HSD

\begin{tabular}{ccccc}
\hline Placement (I) & Placement (J) & Mean Difference (I-J) & Std. Error & Sig. \\
\hline \multirow{2}{*}{ Practicum } & Field-Based & -1.88 & 2.056 & .634 \\
& Student Teaching & -6.15 & 2.527 & .045 \\
Field based & Practicum & 1.88 & 2.056 & .634 \\
& Student Teaching & -4.28 & 1.997 & .089 \\
Student Teaching & & & & \\
& Practicum & 6.15 & 2.527 & .045 \\
& Field-based & 4.28 & 1.997 & .089 \\
\hline
\end{tabular}

\section{Research Question 3}

Is there a difference in the self-efficacy of preservice special education teachers in the factor areas of Classroom Management, Instructional Strategies, and Student Engagement based on their classroom placement?

An ANOVA was performed to evaluate differences between ratings on classroom placement and the three factors (Classroom Management, Instructional Strategies, and Student Engagement). For classroom placement, three options existed: academic, behavioral, and adaptive/life skills. Differences in the outcome variables were assessed across levels of classroom placement. Table 8 shows the descriptive statistics for each. Each line represents an analysis across the three classroom placements. 
Table 8

Differences in Factor Ratings by Classroom Type

\begin{tabular}{|c|c|c|c|c|c|c|c|}
\hline Factor & Source & $d f$ & $F$ & $S S$ & $M S$ & $p$ & $\eta^{2}$ \\
\hline 1 & $\begin{array}{l}\text { Corrected Model } \\
\text { Error }\end{array}$ & $\begin{array}{r}2 \\
73\end{array}$ & .40 & 37.34 & 18.67 & 0.67 & 0.01 \\
\hline 2 & $\begin{array}{l}\text { Corrected Model } \\
\text { Error }\end{array}$ & $\begin{array}{r}2 \\
71\end{array}$ & .35 & 22.35 & 11.17 & 0.70 & 0.01 \\
\hline 3 & $\begin{array}{l}\text { Corrected Model } \\
\text { Error }\end{array}$ & $\begin{array}{r}2 \\
71 \\
\end{array}$ & 1.52 & 179.48 & 89.74 & 0.23 & 0.04 \\
\hline
\end{tabular}

Note. $d f=$ degrees of freedom, $\mathrm{SS}=$ sums of squares, $\mathrm{MS}=$ mean squares, $F=\mathrm{F}$ distribution, $p=$ significance, $\eta^{2}=$ effect size, Factor $1=$ Classroom Management, Factor $2=$ Instructional Strategies, Factor 3=Student Engagement

For factor 1, Classroom Management, the tests of between-subject's effects showed $F(2,73)=0.40, p=0.67, \eta^{2}=0.01$, indicating no significant difference across the levels of classroom type. The $\eta^{2}$ of .01 indicates a small relationship between the Classroom Management factor and classroom type. For factor 2, Instructional Strategies, the tests of between-subject's effects showed $F(2,73)=0.35, p=.70, \eta^{2}=$ 0.01 , indicating no significant difference across the classroom placement. The $\eta^{2}$ of .01 indicates a small relationship between the Instructional Strategies factor and classroom type. For factor 3, Student Engagement, the tests of between-subject's effects showed $F$ $(2,73)=1.52, p=0.23, \eta^{2}=0.04$, indicating no significant difference to the placement factor. The $\eta^{2}$ of .04 indicates a small relationship between the Student Engagement factor and classroom type.

\section{Effect Size and Power}

When estimating the percentage of the variance in the scores of the dependent variables based on the independent variables, several different effect size indexes (e.g. 
Cohen's $d$, partial-eta squared, Pearsons r) can be run (Chemosit, 2012). In this study, with the statistical power set at $\alpha=0.05$, and with running the factorial ANOVAs in SPSS, partial-eta squared effect sizes were generated. The $\eta^{2}$ (partial eta squared) index scores are, 0.02, small, 0.13, medium, and .26, large (Pierce, Block, \& Aguinis, 2004). For question two, all three factor areas showed a small effect size through the $\eta^{2}$ scores. Classroom management $\left(\eta^{2}=0.09\right)$ and Instructional Strategies $\left(\eta^{2}=0.18\right)$ both fell at or above the 0.10 values. Instructional Strategies $\left(\eta^{2}=0.07\right)$ fell just below. For question three, all three factor areas showed slightly less than a small effect size: (a) Classroom management, $\eta^{2}=0.01$; (b) Instructional Strategies, $\eta^{2}=0.01$; (c) Instructional Strategies, $\eta^{2}=0.04$

Obtaining a 0.80 statistical power (or a large difference) is ideal for researchers to decrease the chance of a Type II error (Huck, 2004). Clearly this was not found for this study. The smaller the effect size number, the harder it is to meet the assumptions. For this study, assumptions had mixed results. However, the null hypothesis was rejected for all but Classroom Management in question two.

\section{Chapter Summary}

The goal of this study was to research preservice special education teachers' perceptions related to their self-efficacy in the areas of Classroom Management, Instructional Strategies, and Student Engagement. These participants $(n=74)$ were in one of three clinical placements: (a) practicum, (b) field-based, or (c) student teaching. They were also in one of three classroom placements: (a) academic, (b) behavioral, or (c) life skills/adaptive. For this study, the null hypothesis was that there would be no difference in the mean scores of self-efficacy of preservice teachers in their first placement 
(practicum), their second placement (field based), and their final placement (student teaching) in all three subscores of self-efficacy (Classroom Management, Instructional Strategies, and Student Engagement).

The mean values for each question of this study, using the 24 TSES questions designed by Tschannen-Moran and Hoy (2001), fell between 5.64 (Some Influence) and 7.51 (Quite a Bit). The standard deviations for each of the 24 TSES questions fell between 1.092 and 2.071, while the overall mean scores for the participants of this study were: $\mathrm{CM}(\bar{X}=6.7)$ IS $(\bar{X}=7.2)$ and $\operatorname{SE}(\bar{X}=7.3)$. A factor analysis was completed to see if this populations responses loaded onto the same factors as Tschannen-Moran \& Hoy's (2001), and other major studies (Duffin, et al., 2012; Fives and Buehl, 2009; Poulou, 2007). The results showed that the factors loaded similarly to the original study. Eigenvalues were also computed as part of this data for verification. The Cronbach's alphas were as follows: Student Engagement $(\alpha=0.89)$, Classroom Management $(\alpha=$ 0.87 ), and Instructional Strategies $(\alpha=0.83)$, with a total scale of $\alpha=0.92$. There was a significant difference (.04) in in the self-efficacy beliefs of participants between groups based on the number of hours spent in their clinical placements. A Tukey test was conducted to assess where the significance between group findings occurred. This revealed that the significant difference was evident between participants in their practicum placements and participants in their student teaching placements. There were no significant mean differences in student engagement or instructional strategies based on participants in their clinical placements, and there were no significant differences in participant's self-efficacy when looking at classroom placements. 


\section{CHAPTER V}

\section{SUMMARY, CONCLUSIONS, AND RECOMMENDATIONS}

This chapter provides a description of the research focus and methodology that guided this study. Included in this chapter are: (a) summary of the research problem, methods, and findings; (b) conclusions; (c) implications; (c) limitations; and (d) recommendations for future research.

\section{Summary of the Research Problem, Methods, and Findings}

Research over the last 25 years has shown that preservice teacher candidates enter into their teacher education programs with an abundance of prior knowledge, coming from their own experiences in schools, classrooms, and previous instructional practices (Doolittle et al., 1993; Pajares, 1992). That knowledge, flawed or not, may lead candidates to believe they feel more efficacious than would normally be expected of a new college student. Education is the only field where preservice teachers believe they have expertise before beginning their course work (Fajet et al., 2005).

Self-efficacy, a term that has been known in psychological research for four and a half decades, is a perceived control over outcomes in a person's professional, social and personal life (Schunk \& Zimmerman, 2008). Albert Bandura, credited with coining the term self-efficacy, believed there were four sources: mastery experience, verbal persuasion, vicarious experiences, and the physiological state. Each was critical for increasing and maintaining efficacy. According to Bandura, a person's sense of efficacy changes constantly and it is not necessarily the same given subject areas, tasks, or even 
groups of students (Bandura, 1997).

While there have been numerous studies on this matter (Chesnut \& Cullen, 2014;

Dicke et al., 2014; Duffin et al., 2012; Pendergast et al., 2011), very few have included preservice teachers in their research, and even less have exclusively studied this population. Across teacher preparation programs nationwide, there is a vast difference in the amount of preparation, pedagogy, and field experiences provided for preservice teachers (Darling-Hammond et al., 2002; Freeman et al., 2014). The federal government provides general guidelines, but the requirements for preservice programs are designed by the individual states (Freeman et al., 2014).

This study utilized the TSES (Tschannen-Moran \& Hoy, 2001) and examined undergraduate preservice special education teachers' self-efficacy at a large Midwestern university. This population was chosen because they have the unique opportunity to have three in-depth experiences in the field before graduation. The instrument targeted the self-efficacy of Classroom Management, Instructional Strategies, and Student Engagement. For this study, it also studied the effect of the number of clinical contact hours on self-efficacy. The preservice special education teachers were given the online survey as they worked with students in an elementary, middle, or high school placement with students with academic challenges, behavioral challenges, or in a life skills/adaptive classroom.

A cross-sectional survey design was utilized during the participants' practicum, field-based, and student teaching experiences. This type of design analyzes data from a cross section of the population at one period of time (Vogt, 2007). For this study, it was preservice special education teachers at a large Midwestern university while enrolled in 
their practicum, field based, or student teaching semesters. Demographic questions were also included in the study to target specific preservice special education teacher experiences. A link to the 24-question survey (long version) was sent out via email to the 223 preservice special educators enrolled in week 10 of one of the targeted semester placements in the fall of 2015 . A total of 90 participants started the survey, but only 74 completed it, from which comprised the data that was analyzed. Survey data were collected in an online program, Select Survey, and then transferred into IBM SPSS Statistics.

I ran two ANOVAs that tested whether number of clinical hours and classroom type were associated with a change in each dependent variable (TSES factors). When looking at the difference in the self-efficacy of preservice special education teachers based on the number of clinical contact hours with students in the classroom settings (practicum, field-based, and student teaching semesters), the data showed no significant difference in the areas of Instructional Strategies and Student Engagement. One variable, Classroom Management $\left(\eta^{2}=0.09\right)$, was found to be significant overall between the three levels of placement scores, and the effect size was medium. These overall results were similar to ones found in other literature that focused on preservice teachers where scores for Classroom Management were higher than the other factors (Brown et al., 2015; Shaukat \& Iqbal, 2012).

A Tukey HSD test was then completed for the factor area of Classroom Management. A mean difference of -6.15 was found between the preservice teacher candidates at the practicum level and the student teaching level. This indicates that preservice special education teachers at the practicum level feel significantly less self- 
efficacious with classroom management than preservice special education teachers at the student teaching level. This is consistent with literature that found that the earlier in the program, a preservice teacher is, the less efficacious they feel, and that mastery experiences can increase their self-efficacy (Brown et al., 2015; Duffin et al., 2012; Lee et al., 2012). The participants in this study were in at least week ten of the semester, but still responded that they did not feel efficacious in this area. For practicum preservice special education teachers this equates to about half of their required 40 hours. This lack of efficacy could be because they are still new to the field so they do not see their own skill set, they have not had the exposure or experience to students that the other participants have had, or that they do not feel they have been exposed enough to strategies to help them with classroom management. For these participants, teacher preparation programs can address two of these needs, additional exposure and further research into strategies.

\section{Conclusions}

\section{Reliability of the TSES}

One critical point is that although this was a replication study, this study's population consisted of three different levels of preservice special education teachers. Previous studies, while looking at preservice teachers, focused on one specific group (e.g. just student teachers, or preservice teachers who were in their first class). This study looked at preservice special education teachers as a whole, but also delineated them by amount of time out in the field. This difference is exciting in that it shows the changes in preservice special education teacher perceptions who are in their practicum, field-based and student teaching. seen in the mean difference scores in the areas of Classroom 
Management, Instructional Strategies, and Student Engagement.

\section{Factor Analysis for Research Question 1}

I conducted a reliability analysis on the three factors. For each factor, Cronbach's alphas were, $\alpha=0.87$ for Classroom Management, $\alpha=0.83$ for Instructional Strategies, and $\alpha=0.89$ for Student Engagement. This gave a combined total of $\alpha=0.92$. This study replicated the Tschannen-Moran and Hoy (2001) study by using the same 24-question survey. The test-retest reliability showed similar alpha levels to the study completed by Tschannen-Moran and Hoy (2001) and with other major studies that have been done using the same 24-question survey (Duffin et al., 2012; Fives \& Buehl, 2009; Poulou, 2007). Replication studies, although typically thought of as replication of the information in descriptive statistics, are critical to the field as they marry information found at one piece of time with information found later. Vogt (2007) explains that these types of studies should be called results verification studies as it really describes what happens in research; researchers look for verification of the results of other studies.

The preservice special education teachers at the university where the study took place scored their levels of self-efficacy in the subscale areas of Classroom Management $(\bar{X}=6.7)$, Instructional Strategies $(\bar{X}=7.2$,$) and Student Engagement (\bar{X}=7.3)$, which is almost identical to the study done by Tschannen-Moran and Hoy (2001) that had subscale areas of Classroom Management $(\bar{X}=6.7)$, Instructional Strategies $\bar{X}=$ 7.3) and Student Engagement $(\bar{X}=7.3)$. These scores are equated with the "quite a bit" anchor that Tschannen-Moran and Hoy (2001) assigned to number 7. This is particularly interesting since the 2001 study included in-service teachers, while this study did not. One conclusion could be that two of the group of the preservice special education 
teachers included in this study (field based and student teachers) felt as efficacious as the population studied by the authors of original study because they have several semesters of preparation instead of just a student teaching semester. It must be noted, however, that the group sizes (practicum, field based and student teaching) in this study were vastly different. The majority of participants for this study $(n=47)$ were in their field-based semester. This means they would have been in the classroom setting 40 hours the previous semester and were approximately ten weeks into their 200-hour requirement for their current placement. Even with roughly 190 contact hours, it is surprising that their self-reported scores were as high as the participants in the original study, because the participants in the Tschannen-Moran and Hoy study (2001) had significantly more hours of exposure in the classroom. The overall mean score of $\bar{X}=6.8$ for this study's participants was also comparable to other studies of preservice special educators (Charalambous, Philippou, \& Kyriakides, 2008; O’Neill \& Stephenson, 2012b). These studies found that the more opportunities the preservice special education teachers had to observe and practice in a mastery experience, the more efficacious they felt.

It is absolutely necessary, when using the TSES as a part of a study, to include factor analysis (Tschannen-Moran \& Hoy, 2001). Factor analysis is a technique used to determine if there are factors (clusters of questions that relate to each other), how many there are and to establish what other analysis' need to be complete (t-test vs. ANOVA). A confirmatory factor analyses was conducted on the data to identify if the current study's preservice special education teacher's responses loaded onto one or more factors. In this case, they loaded cleanly onto five factors but were forced to three after following the guidelines set forth by Ellett et al., (1997) and Chemosit (2012). 
The 1-factor vs 3-factor discussion concerning preservice teachers, has been debated in the literature. In this discussion, the authors of four studies (Duffin et al., 2012; Fives \& Buehl, 2009; Poulou, 2007; Tschannen-Moran \& Hoy, 2001) competed a confirmatory factor analysis and looked at which factor structure was most appropriate for preservice teachers. Results of the TSES of the factor structuring for these four studies were mixed. Preservice teachers were included in all studies, but were inconsistent in their year of schooling. Tschannen-Moran and Hoy (2001) alleged the total score for the three factors was the most applicable for measuring self-efficacy as the "subscale scores have little meaning for prospective teachers who have yet to assume real teaching responsibilities" (Tschannen-Moran \& Hoy, 2001, p. 801). Poulou (2007), whose participants were at the end of their student teaching experience, argued that the preservice teachers could tell the difference between the three factors. Fives and Buehl (2009) and Duffin et al. (2012), whose participants were at various stages of their preservice teaching experience, asserted that their participants could not. When looking at the population of this study, with mean scores almost exactly consistent with the original study, it is clear that the preservice teachers could tell the difference between the three factors, as they did in Poulou's 2007 study also only looking at preservice teachers.

\section{Self-Efficacy of Preservice Teachers}

The null hypothesis of this study was that there would be no difference in the selfefficacy skills of preservice special education teachers because the research (Doolittle et al., 1993; Dorel et al., 2016; Pajares, 1992) has shown that preservice teachers feel efficacious when going into a classroom, and when conducting most studies, disproving the null is a standard approach. This study, indicated through the ANOVA analysis, 
determined that this was true for all areas except for the practicum students when looking at the Classroom Management factor. In that instance, through investigating further using a Tukey test, I found that preservice student teachers at the student teaching level feel more efficacious than those at the practicum level. It is my assumption that this is because they have had much more time in the classroom supporting students (since this is their third semester) and they have seen several people (teachers, aides, administrators) model support behavior so they can develop their own systems of behavior management. In the case of instructional strategies and student engagement, these areas are not as easily modeled. Preservice special education teachers have fewer chances to observe how to teach using strategies for learning and engagement. While they may have had much course work regarding these, their ability to utilize what they have learned regarding these topics from their college classroom maybe somewhat limited.

My study shows that preservice special education teachers during their preservice program felt 'quite a bit' of self-efficacy in the area of classroom management $(\bar{X}=6.7)$. I feel this is because they have the mastery experiences in the classroom for more than one semester, verbal feedback from their instructors and cooperating teachers and vicarious experiences that Bandura (1977) felt were critical for effective teaching. The sooner the preservice special education teachers are able to be out in the field in schools, the better they are at learning to manage a classroom so they can help students learn and be successful (Darling-Hammond, 2006).

\section{Implications}

The implications coming from the data are that, study after study, over the last 40 years researchers are finding the same results. Most preservice teachers feel the greatest 
level of efficaciousness in the area of classroom management (Brown, et. al., 2015; Lee, et al., 2012, Sisman, 2014). Boe and colleagues (2007) also found that experiences in the classroom and increased pedagogy preparation were more effective in creating teachers who were not only ready for the classroom but were more successful in their classrooms. They found a more efficacious teacher is able to engage students and utilize instructional strategies to make their students more successful. Preparation through practice is the key to providing preservice special education teachers (and their general education counter parts) the best chance to be successful, and stay in the field.

\section{Limitations}

One of the largest limitations of the study was the unequal sample of participants. When a sampling a population, it is better to do probability sampling where the researcher knows the probability of getting certain people in a population (Vogt, 2007). Because the population chosen was a convenience sample, there was no way to control how many preservice special education teachers from each placement level would complete the survey. Although when doing survey studies there are four types of probability studies, in hindsight I could have chosen a stratified random sampling. This type of random sampling allows groups to be pre-chosen from a population and sampled, and is stratified to include equal representation. However, because the study was sent out to 223 preservice special education teachers in one of three placement semesters, the researcher was bound by random sampling. In random sampling, each member of the population has an equal chance of being selected. The main reason this was chosen was to eliminate bias from the selection of participants. 
Another main limitation of the study is that surveys do not determine causation. I cannot tell from the data why the students scored themselves at the levels that they did, or measure their psychological state. In addition, there were several other limitations to this study. Surveys typically yield a low return rate. On average, an online survey yields a response rate of approximately $11 \%$ lower than other survey modes, such as face-to-face, whose results can vary from $5 \%$ to $80 \%$ (Fan \& Yan, 2010). This survey yielded a 33\% rate and the sample was representative for this population $(\mathrm{N}=223)$. It was weighted heavily by preservice special education teachers in their field-based semester (57\% of respondents). This impacted the analysis of the data because these preservice special education teachers had completed their practicum experience (40 hours) and were at least 10 weeks into their 200-hour field based experience. Preservice special education teachers in their practicum experience may not have the ability to see their own efficacy skills and deficits the same way someone in student teaching may. When they are in their practicum experience, it may the first time they are in schools as a 'teacher' and, for this population, they have only had preparation for the three factor areas (Classroom Management, Instructional Strategies, and Student Engagement) in isolation throughout their program, not as a formal class.

Looking through Bandura's Social Cognitive Theory lens (Bandura, 1986), the preservice student teachers at the practicum level may be just beginning to go through their mastery experience in the classroom, learning from the verbal persuasion of someone in authority they hold in high esteem. Although they may have had some vicarious experiences in their course work, no information is known as this was not a question that was asked. Another major limitation is the fact that self-reported survey 
data tends to be unreliable, leading to the question of whether the respondents completed the questionnaire themselves or if someone else did it for them, both of which is a concern for online surveys (Coughlan, Cronin, \& Ryan, 2009). Preservice teachers may or may not have the correct impressions of their skill sets; overestimating or underestimating their own abilities. This study cannot answer whether preservice teachers are prepared to student teach, only what the participants feel about their own ability.

Another limitation is that the questions may load differently the next time the study is completed. Given a different rate of response, or a changing population the factor loading could be remarkably different. However, while this is possible, I feel the reliability statistics of this study in comparison to the Tschannen-Moran and Hoy study (2001) show that the 24-question instrument and the 3 factors that converged are reliable and that scores would remain stable. When looking as this sample population, compared to the population at large questions could be raised about the generalizability due to the different respondent proportions and even the differences in the demographics. However, the TSES questionnaire has been used by researchers in the United States, German (Dicke et al., 2014), Greece (Poulou, 2007), Israel (Leyser et al., 2011), Turkey (Sisman, 2014) and Asia (Klassen et al., 2009). The TSES has been labeled "superior to previous measures of teacher efficacy in that it has a unified and stable factor structure" (Hoy \& Spero, 2005, p.354).

\section{Recommendations for Future Research}

Future research should include looking at each group (practicum, field based, and student teaching) individually instead of overall, to see where each group scored for each 
factor. It would be interesting to see, if the response rates were more evenly distributed, if there were differences in the results. During the fall semester, the participants of this study were just over $33 \%$ of the total population of preservice special education teachers in their practicum, field based experience or in student teaching. While this is an acceptable return rate for an online survey, if the return rates were better overall, the population would be better represented. This is especially true when looking at the differences in the rates of response between the groups who participated in this study. When the sample is low, it is possible that the population is not being represented appropriately (Coughlan et al., 2009).

Another recommendation would be to complete the survey in spring semester when preservice special education teachers are in an expected placement (i.e., student teachers graduating in their spring semester), and the total number of participants in each placement are more balanced (possibly improving effect size and statistical power). Preservice special education teachers, when following the schedule of a more typical placement, may have different responses to the survey questions since they will have had one more semester where they could have had additional outside experience (summer camp, volunteering, etc.) increasing their perception of their self-efficacy. The results of the study showed that most of the participants were in their field based semester placement. Given an additional few months of experience either in or out of the classroom may show an increase in their self-perceptions.

It would be interesting to see what is embedded in the curriculum of the large Midwestern university that was studied, and review the programs at other universities to see what they are doing with their preservice special education teachers. The literature 
says that preservice teachers are not being educated in the same way (Freeman et al., 2014). However, it does not explain the 'why' of the programing decisions. Is it because the curriculum has been set for a long period of time? Is it because of perceived state or federal restrictions? Or is something else at play.

A test-retest study within this study for a measure of reliability is another recommendation. This could be done to see if the means and standard deviations change from one time in the semester to another. Preservice special education teachers could be studied at the beginning (week 1 or 2 ) of their placement in the field and then again at the end (week 15 or 16). The participants could be surveyed with the addition of asking for the university identification number to assure the responses consistently come from the same person. This could be done online or in a site-based setting. If done in a site-based setting, the researcher could then address one of the limitations of this study, which was response rate within the subgroups of practicum, and field based preservice special education teachers. If done online, response rates could not be controlled.

Future research should encompass looking at a targeted group of preservice special education teachers that can be followed from their practicum to their student teaching semester. This would yield data that could truly identify if any means had changed within the population being studied. More data could be found if the group was then followed into their first year of teaching. Also, there remains the need to conduct qualitative (interview, focus groups etc.) data. This would address the potential factor loading limitations by identifying the areas where the participants were feeling the least/most efficacious and providing targeted instruction for them in those areas. 
It would be interesting to add in a qualitative question section to the study to see if there is some correlation between the scores and the comments of preservice special education teachers. I would also use a stratified random subsample from the first group of participants, choosing an equal amount from each of the subgroups to assure there are equal numbers being represented.

Preservice special education teachers, when following the schedule of a more typical placement (e.g. Student Teaching in the spring semester), may have different responses to the survey questions since they will have had one more semester where they could have had additional outside experience (summer camp, volunteering, etc.) increasing their perception of their self-efficacy. This would make an excellent demographic question, asking the preservice special education teachers if they had outside experiences and then providing them with some examples (day camp, Best Buddies, etc.) from which they could choose.

In addition, the participants were enrolled at one university in the Midwest and were exposed, overall, to more hours in the classroom than reported hours found during an online search of other university programs. The implication is that these particular preservice special education teachers may be more competent in the classroom after they graduate due to the prolonged exposure to working with students. They may outperform their counterparts from other universities. A future area of research could include identifying another university with a similar three-semester experience and look at the self-efficacy similarities and differences between the two populations.

Understanding self-efficacy and the effects it has on preservice teaching ability would provide universities with valuable information when designing classes and 
experiences in the field. This study touched on the areas where this population felt most efficacious. Looking at this data, faculty could gain insight on what needs to be done to create a valuable learning environment so that the preservice teacher's self-efficacy could increase. As the research has shown, only $27 \%$ of IHEs provide a specific class on classroom management (Oliver \& Reschly, 2010). It is clear from the statistical difference found between preservice special education teachers at the practicum level and student teachers that more work needs to be done in the initial special education courses so that the practicum students are walking into classrooms feeling more prepared. Preservice teachers' perceptions of their self-efficacy are a significant factor to their success as future educators (Brownell et al., 2005; Hoy \& Spero, 2005; Pajares, 1992).

\section{Chapter Summary}

Numerous results have found similar results to the TSES, but when looking at the research body as a whole, little to no research has been done on preservice special education teachers. The research completed in this study is important to the special education community in higher education as a whole, as it was able to add to the literature by discussing statistically significant results for preservice special educators in the areas of self-efficacy and classroom management. While the purpose of this study was to look at a specific population at a Midwestern university, the mean scores and standard deviations were similar to that of other study participants using the same tool in other parts of the country. This study is the first of its kind in that it has addressed a gap in the research that is critical for institutions of higher learning by providing a glimpse at the differences in the self-efficacy beliefs of preservice special education teachers at different levels of their program. This study also added to the growing research on the 
confirmatory factor analysis of the TSES, concluding that the preservice special education teachers are able to tell the difference between the three factors, Classroom Management, Instructional Strategies, and Student Engagement. Future research should continue to focus on this understudied population, especially at different points in their undergraduate programming to see if and when self-efficacy changes occur. This can be done by: (a) following a targeted group of students; (b) using a test/retest model; (c) including participants from other universities for comparison, or (d) making course work decisions as needed with an emphasis on classroom management.

Preservice teacher education (as a whole) is fascinating. Working as a special education teacher in many general education classrooms, I was afforded the luxury of seeing teachers with degrees from many universities in action. As a behaviorist in these classrooms how and when a teacher handled the management of their classroom was particularly intriguing. That was why this study was so important to me. I have always wanted to know if teachers felt they were doing a good job in the area of classroom management, if experiences or course work made them feel more prepared, and how that management played out in the classroom when it came to student engagement and utilizing instructional strategies. 


\section{REFERENCES}

Armor, D., Conroy-Oseguera, P., Cox, M., King, N., McDonnell, L., Pascal, A., . . Zellman, G. (1976). Analysis of the school preferred reading program in selected Los Angeles minority schools (Rep. No. R-2007-LAUSD).

Avramidis, E., Bayliss, P., \& Burden, R. (2000). Student teachers' attitudes towards the inclusion of children with special educational needs in the ordinary school. Teaching and Teacher Education, 16, 277-293. doi:10.1016/S0742051X(99)00062-1

Bandura, A. (1977). Self-efficacy: Toward a unifying theory of behavioral change. Psychological Review, 84, 191-215. doi:10.1037/0033-295X.84.2.191

Bandura, A. (1982). Self-efficacy mechanism in human agency. American Psychologist, 37, 122-147. doi:10.1037/0003-066X.37.2.122

Bandura, A. (1986). Social foundations of thought and action: A social cognitive theory.: Englewood Cliffs, NJ: Prentice-Hall.

Bandura, A. (1997). Self-efficacy: The exercise of control.: New York: W.H. Freeman.

Barfield, V., \& Burlingame, M. (1974). The pupil control ideology of teachers in selected schools. The Journal of Experimental Education, 42, 6-11.

Boe, E. E., Shin, S., \& Cook, L. H. (2007). Does teacher preparation matter for beginning teachers in either special or general education? Journal of Special Education, 41, 158-170. doi:10.1177/00224669070410030201 
Brown, A. L., Lee, J., \& Collins, D. (2015). Does student teaching matter? Investigating pre-service teachers sense of efficacy and preparedness. Teaching Education, 26(1), 77-93. doi:10.1080/10476210.2014.957666

Brownell, M. T., Ross, D. D., Colon, E. P., \& McCallum, C. L. (2005). Critical features of special education teacher preparation: A comparison with general teacher education. Journal of Special Education, 38, 242-252.

Caprano, M. M., Caprano, R. M., \& Helfeldt, J. (2010). Do differing types of field experiences make a difference in teacher candidates' perceived level of competence? Teacher Education Quarterly, 37(1), 131-154.

Charalambous, C. Y., Philippou, G. N., \& Kyriakides, L. (2008). Tracing the development of preservice teachers' efficacy beliefs in teaching mathematics during fieldwork. Educational Studies in Mathematics, 67, 125-142.

Chemosit, C. C. (2012). College experiences and student inputs : factors that promote the development of skills and attributes that enhance learning among college students. (Bibliographies, Theses, Non-fiction). Available from EBSCOhost cat00180a database.

Chesnut, S. R., \& Cullen, T. A. (2014). Effects of self-efficacy, emotional intelligence, and perceptions of future work environment on preservice teacher commitment. Teacher Educator, 49, 116-132. doi:10.1080/08878730.2014.887168

Coughlan, M., Cronin, P., \& Ryan, F. (2009). Survey research: Process and limitations. International Journal of Therapy \& Rehabilitation, 16(1), 9-15 
D'Alonzo, B. J., Giordano, G., \& Vanleeuwen, D. M. (1997). Perceptions by teachers about the benefits and liabilities of inclusion. Preventing School Failure, 42(1), 411. doi: $10.1080 / 10459889809603162$

Darling-Hammond, L. (2000). How teacher education matters. Journal of Teacher Education, 51, 166-173. doi:10.1177/0022487100051003002

Darling-Hammond, L. (2006). Constructing 21st-century teacher education. Journal of Teacher Education, 57, 300-314. doi:10.1177/0022487105285962

Darling-Hammond, L., Chung, R., \& Frelow, F. (2002). Variation in teacher preparation: How well do different pathways prepare teachers to teach? Journal of Teacher Education, 53, 286-302. doi:10.1177/0022487102053004002

Dicke, T., Parker, P. D., Marsh, H. W., Kunter, M., Schmeck, A., \& Leutner, D. (2014). Self-efficacy in classroom management, classroom disturbances, and emotional exhaustion: A moderated mediation analysis of teacher candidates. Journal of Educational Psychology, 106, 569-583. doi:10.1037/a0035504

Doolittle, S. A., Placek, J. H., \& Dodds, P. (1993). Persistence of beliefs about teaching during formal training of preservice teachers. Journal of Teaching in Physical Education, 12(4), 355-365.

Dorel, T. G., Kearney, W. S., \& Garza, E. (2016). Ready from day one? The relationship between length of pre-service teacher field residency and teacher efficacy. Critical Questions in Education, 7(1), 38-52.

Duffin, L. C., French, B. F., \& Patrick, H. (2012). The Teachers' Sense of Efficacy Scale: Confirming the factor structure with beginning pre-service teachers. Teaching and Teacher Education, 28, 827-834. doi:10.1016/j.tate.2012.03.004 
Ellett, C. D., Loup, K. S., Culross, R. R., McMullen, J. H., \& Rugutt, J. K. (1997). Assessing enhancement of learning, and student efficacy: Alternatives to traditional faculty evaluation in higher education. Journal of Personnel Evaluation in Education, 11, 167-192.

Fajet, W., Bello, M., Leftwich, S. A., Mesler, J. L., \& Shaver, A. N. (2005). Pre-service teachers' perceptions in beginning education classes. Teaching and Teacher Education: An International Journal of Research and Studies, 21, 717-727. doi:10.1016/j.tate.2005.05.002

Fan, W., \& Yan, Z. (2010). Factors affecting response rates of the web survey: A systematic review. Computers in Human Behavior, 26, 132-139. doi:10.1016/j.chb.2009.10.015

Fives, H., \& Buehl, M. M. (2009). Examining the factor structure of the Teachers' Sense of Efficacy Scale. Journal of Experimental Education, 78(1), 118-134. doi:10.1080/00220970903224461

Fives, H., Hamman, D., \& Olivarez, A. (2007). Does burnout begin with studentteaching? Analyzing efficacy, burnout, and support during the student-teaching semester. Teaching and Teacher Education, 23, 916-934. doi:10.1016/j.tate.2006.03.013

Freeman, J., Simonsen, B., Briere, D. E., \& MacSuga-Gage, A. S. (2014). Pre-service teacher training in classroom management: A review of state accreditation policy and teacher preparation programs. Teacher Education \& Special Education, 37, 106-120. doi:10.1177/0888406413507002 
Gable, R. A., Tonelson, S. W., Sheth, M., Wilson, C., \& Park, K. L. (2012). Importance, usage, and preparedness to implement evidence-based practices for students with emotional disabilities: A comparison of knowledge and skills of special education and general education teachers. Education \& Treatment of Children, 35, 499-520. doi:10.1353/etc.2012.0030

Gettinger, M., Stoiber, K., \& Koscik, R. (2008). Effects of a preparation program focused on accommodating children with challenging behaviors. Teacher Education \& Special Education, 31, 164-181. doi: 10.1177/0888406408330624

Gibson, S., \& Dembo, M. H. (1984). Teacher efficacy: A construct validation. Journal of Educational Psychology, 76, 569-582. doi:10.1037/0022-0663.76.4.569

Green, S. B., \& Salkind, N. J. (2014). Using SPSS for Windows and Macintosh : analyzing and understanding data / Samuel B. Green, Arizona State University, Neil J. Salkind, University of Kansas ( $7^{\text {th }}$ ed.) Boston, MA: Pearson.

Handy, T. C. (2004). Event-related potentials: a methods handbook. United States of America: MIT Press.

Hoffman, K., \& Kunze, R. (1971). Linear algebra. Englewood Cliffs, NJ: Prentice-Hall, Inc.

Huck, S. W., \& Cormier, W. H. (2004). Reading statistics and research. New York, NY: HarperCollins.

IBM Corp. Released 2012. IBM SPSS Statistics for Windows, Version 21.0. Armonk, NY: IBM Corp 
Hoy, A. W., \& Spero, R. B. (2005). Changes in teacher efficacy during the early years of teaching: A comparison of four measures. Teaching and Teacher Education, 21, 343-356. doi:10.1016/j.tate.2005.01.007

Killoran, I., Woronko, D., \& Zaretsky, H. (2014). Exploring preservice teachers' attitudes towards inclusion. International Journal of Inclusive Education, 18, 427-442.

Klassen, R. M., Bong, M., Usher, E. L., Chong, W. H., Huan, V. S., Wong, I. Y. F., \& Georgiou, T. (2009). Exploring the validity of a teachers' self-efficacy scale in five countries. Contemporary Educational Psychology, 34, 67-76. doi:10.1016/j.cedpsych.2008.08.001

Lancaster, J., \& Alan, B. (2007). The design of inclusive education courses and the selfefficacy of preservice teacher education students. International Journal of Disability, Development \& Education, 54, 245-256. doi:10.1080/10349120701330610

Lee, J., Tice, K., Collins, D., Brown, A., Smith, C., \& Fox, J. (2012). Assessing student teaching experiences: Teacher candidates' perceptions of preparedness. Educational Research Quarterly, 36(2), 3-19.

Leko, M. M., Brownell, M. T., Sindelar, P. T., \& Murphy, K. (2012). Promoting special education preservice teacher expertise. Focus on Exceptional Children, 44(7), 116.

Leyser, Y., Zeiger, T., \& Romi, S. (2011). Changes in self-efficacy of prospective special and general education teachers: Implication for inclusive education. International Journal of Disability, Development and Education, 58, 241-255. doi:10.1080/1034912X.2011.598397 
Maurer, T. J., \& Pierce, H. R. (1998). A comparison of likert scale and traditional measures of self-efficacy. Journal of Applied Psychology, 83, 324-329.

Merriam, S. B. (1998). Qualitative research and case study applications in education / Sharan B. Merriam: San Francisco : Jossey-Bass, c1998. 2nd ed.

Moulding, L. R., Stewart, P. W., \& Dunmeyer, M. L. (2014). Pre-service teachers' sense of efficacy: Relationship to academic ability, student teaching placement characteristics, and mentor support. Teaching and Teacher Education, 41, 60-66. doi:10.1016/j.tate.2014.03.007

O’Neill, S., \& Stephenson, J. (2012a). Does classroom management coursework influence pre-service teachers' perceived preparedness or confidence? Teaching and Teacher Education, 28, 1131-1143. doi:10.1016/j.tate.2012.06.008

O’Neill, S., \& Stephenson, J. (2012b). Exploring Australian pre-service teachers sense of efficacy, its sources, and some possible influences. Teaching and Teacher Education, 28, 535-545. doi:10.1016/j.tate.2012.01.008

Oliver, R. M., \& Reschly, D. J. (2010). Special education teacher preparation in classroom management: Implications for students with emotional and behavioral disorders. Behavioral Disorders, 35, 188-199.

Pajares, M. F. (1992). Teachers' beliefs and educational research: Cleaning up messy construct. Review of Educational Research, 62, 307-332. doi:10.3102/00346543062003307

Pendergast, D., Garvis, S., \& Keogh, J. (2011). Pre-service student-teacher self-efficacy beliefs: An insight into the making of teachers. Australian Journal of Teacher Education, 36(12), 46-57. doi:10.14221/ajte.2011v36n12.6 
Pierce, C. A., Block, R. A., \& Aguinis, H. (2004). Cautionary Note on Reporting EtaSquared Values from Multifactor ANOVA Designs. Educational \& Psychological Measurement, 64(6), 916-924. doi:10.1177/0013164404264848

Poulou, M. (2007). Personal teaching efficacy and its sources: Student teachers' perceptions. Educational Psychology, 27(2), 191-218.

Regan, K. S. (2009). Improving the way we think about students with emotional and/or behavioral disorders. Teaching Exceptional Children, 41(5), 60-65.

Rokeach, M. (1968). Beliefs, attitudes, and values: A theory of organization and change. San Francisco, CA: Jossey-Bass.

Ross, J. A. (1992). Teacher efficacy and the effects of coaching on student achievement. Canadian Journal of Education, 51-65.

Rotter, J. B. (1966). Generalized expectancies for internal versus external control of reinforcement. Psychological Monographs, 80(1), 1-28. doi:10.1037/h0092976

Schunk, D. H. (1983). Developing children's self-efficacy and skills: The roles of social comparative information and goal setting. Contemporary Educational Psychology, 8, 76-86. doi:10.1016/0361-476X(83)90036-X

Schunk, D. H., \& Zimmerman, B. J. (2007). Influencing children's self-efficacy and selfregulation of reading and writing through modeling. Reading \& Writing Quarterly, 23(1), 7-25. doi:10.1080/10573560600837578

Schunk, D. H., \& Zimmerman, B. J. (2008). Motivation and self-regulated learning: theory, research, and applications. New York, NY: Lawrence Erlbaum Associates. 
Shaukat, S., \& Iqbal, H. M. (2012). Teacher self-efficacy as a function of student engagement, instructional strategies and classroom management. Pakistan Journal of Social \& Clinical Psychology, 10(2), 82-86.

Shillingford, S., \& Karlin, N. (2014). Preservice teachers' self-efficacy and knowledge of emotional and behavioural disorders. Emotional \& Behavioural Difficulties, 19, 176-194. doi:10.1080/13632752.2013.840958

Sisman, G. T. (2014). Teaching certificate program students' sense of efficacy and views of teacher preparation. Procedia - Social and Behavioral Sciences, 116, 20942099. doi:10.1016/j.sbspro.2014.01.526

Stuart, C., \& Thurlow, D. (2000). Making it their own: Preservice teachers' experiences, beliefs, and classroom practices. Journal of Teacher Education, 51, 113-121. doi:10.1177/002248710005100205

Tschannen-Moran, M., \& Hoy, A. W. (2001). Teacher efficacy: Capturing an elusive construct. Teaching and Teacher Education, 17, 783-805. doi:10.1016/S0742051X(01)00036-1

Tschannen-Moran, M., \& Hoy, A. W. (2007). The differential antecedents of selfefficacy beliefs of novice and experienced teachers. Teaching and Teacher Education, 23, 944-956. doi:10.1016/j.tate.2006.05.003

Tschannen-Moran, M., Hoy, A. W., \& Hoy, W. K. (1998). Teacher efficacy: Its meaning and measure. Review of Educational Research, 68, 202-248. doi:10.3102/00346543068002202

Vogt, W. P. (2007). Quantitative research methods for professionals: Boston, MA: Pearson, c2007. 
Woodcock, S., \& Reupert, A. (2013). Does training matter? Comparing the behaviour management strategies of pre-service teachers in a four-year program and those in a one-year program. Asia-Pacific Journal of Teacher Education, 41(1), 84-98. doi:10.1080/1359866X.2012.753991

Woolfolk, A. E., Rosoff, B., \& Hoy, W. K. (1990). Teachers sense of efficacy and their beliefs about managing students. Teaching and Teacher Education, 6, 137-148. doi:10.1016/0742-051X(90)90031-Y

Woolfson, L. M., \& Brady, K. (2009). An Investigation of factors impacting on mainstream teachers' beliefs about teaching students with learning difficulties. Educational Psychology, 29, 221-238. doi:10.1080/01443410802708895

Yakar, Z., Can, B., \& Besler, H. (2013). Does the teaching program effect on pre-service teachers' self-regulation? International Journal of Academic Research, 5, 93-101. doi:10.7813/2075-4124.2013/5-3/B.16 
APPENDIX A

EMAIL REQUEST FOR ACCESS TO CLASS LISTS 
Dear

My name is Alice Cahill and I am completing a survey study as part of the requirements to complete my doctoral degree at Illinois State University. My chairperson is Dr. Mark Zablocki. The title of my research study is Understanding the Differences of the Self-Efficacy Beliefs of Preservice Learning and Behavioral Specialists during their Practicum and Student Teaching Semesters.

I am writing you this request to obtain access to the class lists and email addresses for students who are in their practicum, field based, and student teaching semesters. Using the Teachers Self Efficacy Scale by Tschannen-Moran and Hoy (2001), I am doing an online survey hoping to learn whether preservice teachers feel more efficacious in the area of classroom management, student engagement, or instructional strategies.

Please let me know if I can have access to the class lists, and what the best way would be to obtain them to enter in to Select Survey. If you have any questions or concerns, please feel free to call me on my cell at Thank you, Alice Cahill 
APPENDIX B

RECRUITMENT EMAIL 
Dear Clinical student:

Congratulations on being out in the classroom!

My name is Alice Cahill and I am a doctoral candidate under the direction of Dr. Mark Zablocki in the Department of Special Education at Illinois State University. I have been in the field of special education since 1996 and began my education exactly where you did, at ISU (Go Redbirds!). Throughout my career working with students with academic and behavioral challenges, I have always been interested in preservice education. I informally interviewed student teachers all of the time on whether they thought they had gotten a good education, had enough practicum experience and what they thought the field of special education still needed. When I started my doctorate in 2010 , I researched more about self-efficacy, or the confidence someone has to complete the things they need to do in their job. I saw what a difference a little confidence made in student teachers and I wondered how they viewed their own self-efficacy. I wondered what areas they felt the most efficacious in and why. That led me to my dissertation topic.

This fall I am conducting a research study investigating a few things. I want to know if preservice special education teachers' sense of self-efficacy is strongest in the areas of classroom management, student engagement, or instructional strategies. I want to understand if the amount of clinical hours really makes a difference. And, I want to know if you feel more efficacious based on the students you are working with in the classroom.

I need your help. I would like you to complete a survey, which will take no more than 10-15 minutes to complete. All information will remain anonymous, and your participation is voluntary. Your cooperating teacher and university supervisor will not see any answers, so please be as honest as you can.

If you are interested in participating, please go to: questions please contact me at If you have any at 309-451-5614 or mszablo@illinoisstate.edu.

If you have any questions about your rights as a subject/participant in this research, or if you feel you have been placed at risk, you can contact the Research Ethics \& Compliance Office at Illinois State University at (309) 438-2529 and/or rec@ilstu.edu.

Thank you for your time and your consideration of this study. I really couldn't do it without you!

Sincerely,

Alice Cahill 
APPENDIX C

CONSENT FORM 
[This will appear at the beginning of the online survey]

You are being asked to participate in a research study that I am completing under the direction of Dr. Mark Zablocki in the Department of Special Education at Illinois State University to fulfill the requirements of my Doctoral degree. This study examines factors that influence a preservice special education teachers' sense of self-efficacy when working with students with academic and behavioral needs.

I am requesting your participation in a survey study. The main survey has 24 questions and will take about 10-15 minutes to complete. There are also a few questions asking for demographic information. Please complete all questions.

Your participation is voluntary and all information will be anonymous. No identifying information about you, your location where you are completing this survey, your specific school placement, or your specific responses to the questions is collected from your computer nor can it be retained by the online survey system. No identifiable information about you, or provided by you during this research, can be or will be disclosed to others by the researchers. Your name will not be used in any report or presentation in which the results will be discussed. As a participant, you are able to withdraw from the survey at any time.

There are some risks to participating in the survey. There may be a slight risk for discomfort in answering some of the questions because of the topic being explored. However, you may withdraw from the study at any point for any reason by exiting the survey. Responses to surveys that are not completed and submitted are not retained. The district where you are placed may have software that closely monitors the computer use and activity of students and staff. Because of this, you may wish to complete this survey on a personal computer at a location other than school.

If you have any questions, please contact me at $\quad$ or or Dr. Mark Zablocki at 309-451-5614 or mszablocki@illinoisstate.edu. If you have any questions about your rights as a subject/participant in this research, or if you feel you have been placed at risk, you can contact the Research Ethics \& Compliance Office at Illinois State University at (309) 438-2529 and/or rec@ilstu.edu.

Thank you for your time and your consideration of this study.

Sincerely,

Alice Cahill

Doctoral Candidate

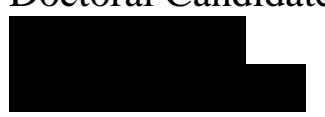


APPENDIX D

SURVEY DEMOGRAPHICS 
Please select the answer that best describes you.

With which gender do you identify??

- Male

- Female

- Prefer not to answer

What is your age?

- 18

- 19

- 20

- 21

- 22

- 23

- 24

- 25

- 26

- 27 or older

Which racial group do you identify with most?

- White/Caucasian

- Black/African American

- Black/non-African American

- Hispanic/Latino

- Asian

- Native American

- Other/Not listed here

How many urban redesign courses have you taken at Illinois State University?

- 0

- 1

- 2

- 3

- 4

- 5

- 6

- More than 6

What is your major?

- LBSI

- Dual Major

- $\quad$ Other, please specify 
Which semester of placement are you in?

- Practicum

- $\quad$ Field based

- $\quad$ Student Teaching

This semester are you working this semester with students who are primarily

- Academic

- Behavioral

- $\quad$ Adaptive/Life Skills

At what level are you currently teaching?

- Elementary

- Middle school

- High school

If participants identified that they were in their field-based placement or their student teaching placement, they were asked the following questions:

In practicum, at what level did you teach?

- $\quad$ Elementary

- Middle School

- High School

In practicum, what type of students were you working with primarily?

- Academic

- Behavioral

- $\quad$ Adaptive/Life Skills

If participants identified that they were in their student teaching placement, they were asked the following questions:

In field based, at what level did you teach?
- $\quad$ Elementary
- $\quad$ Middle School
- High School

In field based, what type of students were you working with primarily?
- Academic
- Behavioral
- $\quad$ Adaptive/Life Skills 


\section{APPENDIX E}

THE TEACHERS' SENSE OF EFFICACY SCALE

(TSCHANNEN-MORAN \& HOY, 2001) 
Directions: This questionnaire is designed to help us gain a better understanding of the kinds of things that create difficulties for teachers in their school activities. Please indicate your opinion about each of the statements below. Your answers are confidential.
(1) Nothing
(7) Quite a Bit
(3) Very Little
(9) I can do a Great Deal
(5) Some Influence

1. How much can you do to get through to the most difficult students?

2. How much can you do to help your students think critically?

3. How much can you do to control disruptive behavior in the classroom?

4. How much can you do to motivate students who show low interest in schoolwork?

5. To what extent can you make your expectations clear about student behavior?

6. How much can you do to get students to believe they can do well in schoolwork?

7. How well can you respond to difficult questions from your students?

8. How well can you establish routines to keep activities running smoothly?

9. How much can you do to help your student's value learning?

10. How much can you gauge student comprehension of what you have taught?

11. To what extent can you craft good questions for your students?

12. How much can you do to foster student creativity?

13. How much can you do to get the children to follow classroom rules?

14. How much can you do to improve the understanding of a student who is failing?

15. How much can you do to calm a student who is disruptive or noisy?

16. How well can you establish a classroom management system with each group of students?

17. How much can you do to adjust your lessons to the proper level for individual students?

18. How much can you use a variety of assessment strategies?

19. How well can you keep a few problem students from ruining an entire lesson?

20. To what extent can you provide an alternative explanation or example when students are confused? 
21. How well can you respond to defiant students?

22. How much can you assist families in helping their children do well in school?

23. How well can you implement alternative strategies in your classroom?

24. How well can you provide appropriate challenges for very capable students? 